Review

\title{
Immune Adjuvant Effect of Molecularly-defined Toll-Like Receptor Ligands
}

\section{Deana N. Toussi and Paola Massari *}

Section of Infectious Diseases, Department of Medicine, Boston University School of Medicine, Boston, MA 02118, USA; E-Mail: Deana.Toussi@bmc.org

* Author to whom correspondence should be addressed; E-Mail: pmassari@bu.edu; Tel.: +1-617-414-4807; Fax: +1-617-414-5280.

Received: 11 February 2014; in revised form: 27 March 2014 / Accepted: 28 March 2014 /

Published: 25 April 2014

\begin{abstract}
Vaccine efficacy is optimized by addition of immune adjuvants. However, although adjuvants have been used for over a century, to date, only few adjuvants are approved for human use, mostly aimed at improving vaccine efficacy and antigen-specific protective antibody production. The mechanism of action of immune adjuvants is diverse, depending on their chemical and molecular nature, ranging from non-specific effects (i.e., antigen depot at the immunization site) to specific activation of immune cells leading to improved host innate and adaptive responses. Although the detailed molecular mechanism of action of many adjuvants is still elusive, the discovery of Toll-like receptors (TLRs) has provided new critical information on immunostimulatory effect of numerous bacterial components that engage TLRs. These ligands have been shown to improve both the quality and the quantity of host adaptive immune responses when used in vaccine formulations targeted to infectious diseases and cancer that require both humoral and cell-mediated immunity. The potential of such TLR adjuvants in improving the design and the outcomes of several vaccines is continuously evolving, as new agonists are discovered and tested in experimental and clinical models of vaccination. In this review, a summary of the recent progress in development of TLR adjuvants is presented.
\end{abstract}

Keywords: TLR; vaccine adjuvant; immune response; microbial pathogens; cancer 


\section{Introduction}

The main goal of vaccination is to induce immunologic protection from infectious diseases of bacterial, viral and parasitic origin. Host immune responses to a given vaccine antigen can be greatly enhanced by simultaneous administration of an immune adjuvant. Adjuvants are exogenous substances that have a wide variety of nature and origin, ranging from mineral salts, oil and water-based emulsions, polymers, microparticles, liposomes, saponins, microbial products and even cytokines [1-3].

Despite the importance of their influence on the immune response, the mechanisms of action by which most adjuvants potentiate innate and adaptive immunity have only recently begun to be understood. Adjuvants are generally categorized into delivery systems and immunostimulatory adjuvants. Delivery systems, particulate adjuvants and emulsions including alum [4], water-in-oil and oil-in-water emulsions (i.e., Complete Freund's Adjuvant (CFA) [5] or MF59 [6]) are thought to generate an antigen depot at the site of injection, which is then slowly released over time (although other factors have been described to contribute to the effect of alum and MF59, for example [7,8]). This process leads to enhanced antigen uptake and presentation by antigen presenting cells (APCs) and induction of high antigen-specific antibody titers. The second category of vaccine adjuvants, immunostimulatory substances, enhances immune responses via a direct effect on immune cell activation and function. These adjuvants induce: (1) upregulation of surface expression levels of the major histocompatibility complexes I and II (MHC I and MHC II) on APCs and enhanced antigen presentation to the T-cell receptor (TCR) (Signal 1); (2) APC maturation/activation and increased surface expression of co-stimulatory molecules (CD40, CD80, CD86) needed for proper activation of naïve T cells (Signal 2); (3) direct and indirect immunomodulation and differentiation of $\mathrm{T}$ lymphocytes; 4) recruitment of immune cells at the site of injection and migration to the draining lymph nodes [9]. In addition, both categories of adjuvants induce immune cell responses mediated by inflammatory mediators (i.e., cytokines and chemokines (signal 3)) [9] and surface receptors/adhesion molecules. The convergence of the events elicited by immune adjuvants leads to enhanced adaptive immune responses and subsequent immune protection, particularly through the activation of dendritic cells (DC) and T cells [10].

It has also been established that activation of APCs occurs via specific recognition of microbial products, a step that has been defined as Signal 0 [9], and is required for innate immune responses that guide T helper cells towards Th1-, Th2- and Th17-type differentiation. Th1-type responses are defined by the pro-inflammatory cytokines IL-12, IFN- $\gamma$ and TNF- $\alpha$, by high levels of IgG2a/b (or IgG2c), IgG3 and IgA in mice, and IgG1, IgG3 and IgA in humans, cell-mediated immunity (CMI) via both $\mathrm{CD}^{+} \mathrm{T}$ cells and $\mathrm{CD} 8^{+}$cytotoxic $\mathrm{T}$ cells (CTLs) (although the latter also require antigen presentation via MHC class I). Th2-type responses are defined by IL-4, IL-5, IL-6, IL-10 and IL-13 and CD4 ${ }^{+} \mathrm{T}$ cell-dependent B cell-mediated humoral immunity via induction of IgG1 and IgE/ IgA in mice or IgG4 and IgE in humans [11]. Dysregulation of Th1-type responses to self-antigens or the commensal flora leads to tissue destruction and chronic inflammation, while dysregulation of Th2-type responses is implicated in allergy and asthma. Recently, Th17-type responses, characterized by IL-17 and IL-23 [12] have been described to modulate neutrophil recruitment [13], and $\mathrm{B}$ and $\mathrm{T}$ cell functions, including those of regulatory $\mathrm{T}$ cells (Treg) [14], thus playing a role in vaccine development [15]. Therefore, inclusion of adjuvants in vaccine formulations is important for both stimulation of innate immunity and induction of improved antigen-specific adaptive responses. 
Various adjuvants have been shown to mediate different types of adaptive immune responses. For example, alum (the first USDA-licensed adjuvant approved for use in humans in the US and present in over $80 \%$ of the licensed human vaccines) stimulates Th2-type responses and strong antigen-specific IgG1 and IgE antibody production, but it does not induce $\mathrm{CD}^{+} \mathrm{T}$-cell immunity and may even inhibit Th1-type immune responses [16]. By contrast, adjuvants such as QS-21 (a saponin from the Soap bark tree Quillaja saponaria in an oil-in-water emulsion), MF59 or Freund's complete adjuvant (CFA) induce preferentially Th1-skewed responses, or a mixed Th1/Th17-type and Th1/Th2-type immunity [3].

In the early 1990s, the potential for a number of bacterial and viral components to act as immune adjuvants has been elucidated by their ability to interact with specific host cell receptors that recognize microbial molecular patterns, the Toll-like receptor family (TLRs) [17]. The role of TLRs in regulation of host innate and adaptive immune responses has been explained by their ability to induce activation of immune cell signaling. In B cells, TLR signaling induces up-regulation of surface markers involved in antigen up-take (MHC I and MHC II) and in cross-talk with T cells (CD40, CD80, CD86), ultimately enhancing antigen-specific antibody production when TLR ligands are used combined with antigens in the context of vaccination. In addition, TLR signaling also plays a role in induction of B- and T-cell memory. In APCs, including B cell, DCs and macrophages, TLR signaling also results in enhanced secretion of both pro- and anti-inflammatory mediators that drive development of $\mathrm{T}$ helper cell subsets into Th1-, Th2- or Th17-type, depending on the type of APC involved [18]. Generally, signaling via TLR3, TLR4, TLR7, TLR8 and TLR9 promotes Th1-type immune responses while signaling via TLR2 (along with TLR1 or TLR6) and TLR5 favors Th2-type immune responses [19,20]. TLR ligands also influence Treg development [21]. A direct influence of TLR signaling on Treg development has been shown, due to expression of functional TLRs on these cells, as well as an indirect effect, due to Treg interaction with TLR-activated APCs [22]. TLR signaling can lead to either Tregs functional activation or suppression, depending on the TLR ligand type and effect on antagonistic induction of Th17 cells [21]. This aspect is particularly relevant for cancer, autoimmunity and chronic inflammation, due to the effects of Th17-type cytokines (IL-17A, IL-17F and IL-22) [21,23]. This review discusses the mechanisms of action of TLR agonists with vaccine adjuvant properties and highlights their potential use to improve vaccination against infectious diseases and cancer.

\section{TLR Signaling Mechanism and Pathways}

Toll-like receptors (TLRs) comprise members of a family of related trans-membrane proteins that recognize microbial and viral products. TLRs have been categorized as pattern recognition receptors (PRRs) that recognize ligands from pathogenic microorganisms (the "pathogen-associated molecular patterns" (PAMPs) [24]), from commensal organisms (the "commensal-associated molecular patterns" (CAMPs) [25]) and endogenous ligands deriving from damaged cells (the "danger-associated molecular patterns" (DAMPs)) [26].

The structure of TLRs is that of horse-shoe shaped proteins composed of three domains: an extracellular or cytoplasmic leucine-rich repeat (LRR) domain which mediates ligand recognition, a single trans-membrane domain, and an intra-cytoplasmic domain, the TIR domain, homologous to the corresponding intracellular domain of the IL-1 receptor (IL-1R) Toll/IL-1R [17]. In humans, 10 TLRs have been identified so far. TLR1, TLR2, TLR4, TLR5, TLR6 and TLR10 are surface-expressed 
and recognize extracellular ligands and microorganisms, while TLR3, TLR7, TLR8 and TLR9 are situated on endosomal membranes within the cell and are engaged by intracellular ligands and microrganisms [17]. Ligand binding and TLR homo- or heterodimerization brings the TIR domains of adjacent TLRs together, providing a conformational change necessary to trigger signaling. Binding of additional adaptor proteins is also essential for intracellular cascades. Adaptor proteins include the myeloid differentiation factor 88 (MyD88) [27], the MyD88 adaptor-like protein (Mal/TIRAP), the TIR domain-containing adaptor protein inducing interferon- $\beta$ (TRIF/TICAM) and the TRIF-related adaptor molecule (TRAM) [28,29] (Figure 1). Negative regulators of TLR function have also been identified and include the Toll-interacting protein (Tollip), IRAK-M, the $\alpha$ - and HEAT-Armadillo-motif-containing protein (SARM) and the B cell adaptor for PI3K (BCAP) [30].

Figure 1. Schematic cartoon of Toll-like receptor (TLR) signaling [17,24,27-30]. Extracellular TLR homodimers (TLR4 and TLR5) are represented in black; heterodimers of TLR2 and TLR1, TLR6 or TLR10 are indicated in black/green. Intracellular homodimers (TLR3, TLR7, TLR8 and TLR9) are indicated in gray.

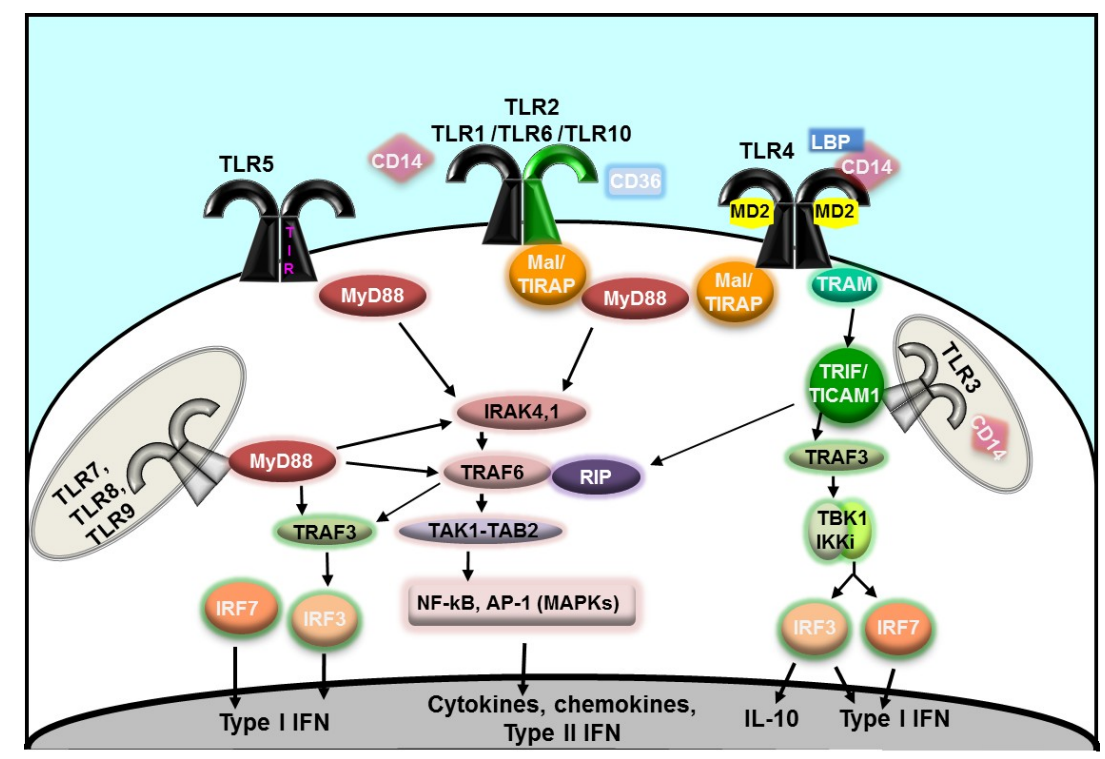

All TLRs except TLR3 require MyD88 recruitment to the TIR domain for signaling activity [27]. TLR2 and TLR4 also require the cooperation of the adaptor protein Mal/TIRAP. In the MyD88-dependent signaling pathway, activation of IRAK4 and IRAK1 (members of the IL-1R-associated protein kinases (IRAKs) [31]) is followed by that of TRAF6 (tumor necrosis factor receptor-associated factor 6 [32]) and RIP (receptor interacting protein [33]), with subsequent signal transfer to a complex made of TAK1 (TGF- $\beta$-activated kinase 1 ), TAB1, TAB2 and TAB3 (TAK1-binding proteins 1,2 or 3 ) and, ultimately, activation of $\mathrm{NF}-\kappa \mathrm{B}$ and, through members of the mitogen-activated protein kinase (MAPK) family (ERK, JNK, p38), activation of AP-1 [34]. The MyD88-dependent TLR signaling pathway leads to host cell responses involved in cell survival/proliferation and immune pathways culminating with immune cell activation, induction of inflammatory mediators and antimicrobial products. Signaling through TLR7, TRL8 and TLR9 also activates a parallel MyD88-dependent cascade through IRF7 (interferon regulatory factor 7 [35]), followed by TRAF6, IRAK4 and TRAF3 activation and leading to type I interferons (IFN) production (Figure 1). 
TLR3 signaling activates a MyD88-independent pathway via TRIF and TRAF3 [36], leading to activation of IRF3 and resulting in secretion of IFN- $\beta$ and IL-10 (Figure 1). The TLR3-TRIF signaling also drives activation of MyD88-dependent pathway downstream components, TRAF6 and RIP1, converging on activation of NF- $\mathrm{BB}$ and AP-1. Similar to TLR3 signaling, TLR4 can also induce MyD88-independent signaling, although TRIF recruitment is not direct but requires prior activation of TRAM. Downstream cell activation via both TRAF6/RIP1, as well as TRAF3-IRF3, provides an amplification of the cytokine repertoire (Figure 1).

\section{TLR Adjuvants with a Preferential Th1-bias}

\subsection{TLR3-Dependent Adjuvants}

TLR3 (CD283) is expressed in endosomal compartments in myeloid dendritic cells (mDCs) and, weakly, in monocyte-derived macrophages [37] and it recognizes viral double-stranded RNA (dsRNA) that is produced during viral replication in infected cells, with the potential contribution of CD14 [38]. A synthetic analog of dsRNA, Poly I:C (polyriboinosinic:polyribocytidylic acid) [39], has similar immunostimulatory properties, inducing TLR3 activation via the TRIF/TRAM pathway and secretion of inflammatory cytokines and IFN- $\beta$ (Figure 1). However, Poly I:C also interacts with other receptors, such as the retinoic acid-inducible gene I (RIG-I), melanoma differentiation-associated gene 5 (MDA-5) and double stranded RNA-dependent protein kinase [40], which may possibly influence its adjuvant activity. Nevertheless, since TLR3 ligands favor strong cellular Th1-type immune responses, they have been tested as adjuvants in vaccines against viral infections. Activation of dendritic cells by TLR3 agonists not only contributes to induction of innate and adaptive immune responses against microbial pathogens, but also favors NK cell activation and killing of tumor cells by stimulating anti-tumor $\mathrm{CD}^{+} \mathrm{T}$ cells [41].

Poly I:C has been used as an adjuvant in various experimental vaccine models. However, the major draw-backs of Poly I:C are its low stability and toxic side-effects. Pre-clinical studies carried out in primates have shown that Poly I:C is easily degraded by serum nucleases, with a consequent reduction of IFN secretion and anti-tumor activity [42]. Unfortunately, increasing the dosage of Poly I:C has not proven a successful strategy, as this TLR3 ligand is not well-tolerated. Thus, several derivatives of Poly I:C have been synthetized and tested for safety and adjuvanticity, such as Poly ICLC and Poly I:C12U (Table 1).

Poly I:C favors antigen cross-presentation to primed $\mathrm{CD}^{+} \mathrm{T}$ cells, due to TLR3-dependent increased MHC class I expression and type I IFN secretion, as well as development of antigen-specific cytotoxic T cell clones [43]. Poly I:C inclusion in an HIV vaccine based on purified recombinant gp120 antigen has shown development of MHC class I-restricted $\mathrm{CD}^{+}$cells in vivo [44]; in another HIV vaccine strategy, addition of Poly I:C (and CpG DNA) to DNA encoding for a Gag antigen/anti-DEC205 antibody fusion protein has shown improved mucosal antigen presentation on MHC class I molecules and enhanced $\mathrm{CD}^{+} \mathrm{T}$ cell-mediated immunity [45]. Several studies in experimental animal models support the efficacy of vaccine formulations containing TLR3-based adjuvants [46]. In the quest for vaccines against cancer, the use of Poly I:C has shown enhancement of tumor specific T cell responses [47]. For example, in an ovarian cancer vaccine, Poly I:C enhances DC maturation and IL-12 secretion [48]. 
Poly I:CLC (Hiltonol ${ }^{\circledR}$ ) is a synthetic double-stranded polyriboinosinic-polyribocytidylic acid stabilized with poly-L-lysine carboxymethyl cellulose and is less sensitive to serum-degradation [49]. Poly ICLC induces high IFN- $\gamma$ secretion and enhances CTL responses and antigen-specific antibody titers, although mild to severe side effects have been reported when it is used at high doses [50,51]. Poly ICLC is currently being tested in clinical trials for both tumors and infectious diseases.

Table 1. Examples of TLR adjuvants, disease models tested in experimental and clinical trials, and human vaccines. Disease models and corresponding vaccines are shown in bold.

\begin{tabular}{|c|c|c|c|}
\hline TLR & Ligand & Disease Models & Human Vaccine \\
\hline$T L R 3$ & $\begin{array}{c}\text { Poly I:C, } \\
\text { Poly I:CLC (Hiltonol), } \\
\text { Poly I:C12U (Ampligen), } \\
\text { Poly I:C + CAF01 (CAF05) }\end{array}$ & $\begin{array}{l}\text { HIV }[44,45,52], \text { HPV }[51], \\
\text { Influenza }[46,53] \\
\text { Cancer }[47,48,50,54]\end{array}$ & \\
\hline$T L R 4$ & $\begin{array}{l}\text { Monophosphoryl Lipid A (MPL), } \\
\text { RC-529 (Ribi), } \\
\text { MPL/QS-21/liposomes (AS01), } \\
\text { MPL/QS-21/oil-in-water } \\
\text { emulsion (AS02), } \\
\text { MPL + Alum (AS04), } \\
\text { MPL + DETOX, AGPs, } \\
\text { GLE-(SE), E6020, OM-174, }\end{array}$ & $\begin{array}{c}\text { HBV [55-59], } \\
\text { Leishmania [60], TB [61,62], } \\
\text { VZV [63], Malaria [64-67], } \\
\text { HIV [68,69], HPV [70-73], } \\
\text { HSV [74], EBV [75], } \\
\text { Melanoma [76,77], } \\
\text { Cancer [78-80] } \\
\text { RSV [81], L. monocytogenes [81], } \\
\text { Influenza [81,82] }\end{array}$ & $\begin{array}{l}\text { Supervax/Fendrix } \\
\qquad[55,58,59], \\
\text { Cervarix }[72,73], \\
\text { Melacine [76], } \\
\text { Stimuvax [78], } \\
\text { Theratope [79] }\end{array}$ \\
\hline $\begin{array}{l}\text { TLR7 } \\
\text { TLR8 }\end{array}$ & $\begin{array}{l}\text { Imiquimod ( } R-837) \text {, Resiquimod } \\
\qquad(R-848)\end{array}$ & $\begin{array}{c}\text { HPV [83,84], Molluscum [84], } \\
\text { Cancer [83-86], Melanoma [87], HIV } \\
\text { [88], HSV [88], Leishmania [89] }\end{array}$ & Aldara [83-87] \\
\hline TLR9 & $\begin{array}{c}\text { CpG ODN, CpG ODN + } \\
\text { MPL/QS21 (AS15) }\end{array}$ & $\begin{array}{c}\text { Malaria [90-92], } \\
\text { Influenza [93], } \\
\text { HBV [94-97], Anthrax [98], HPV [99], } \\
\text { Cancer [99-103], } \\
\text { Melanoma [100,102,104,105], }\end{array}$ & $\begin{array}{c}\text { Fluarix }[93], \\
\text { Engerix-B }[96], \\
\text { Heplisav }[97]\end{array}$ \\
\hline $\begin{array}{l}\text { TLR2/TLR1 } \\
\text { TLR2/TLR6 }\end{array}$ & $\begin{array}{l}\text { Lipoproteins, MALP-2, } \mathrm{Pam}_{2} \mathrm{CSK}_{4} \text {, } \\
\text { Pam }_{3} \mathrm{CSK}_{4} \text {; non-lipidated ligands: } \\
\text { porins (Neisseriae, F. nucleatum, } \\
\text { Chlamydia, Salmonella, Shigella), } \\
\text { toxins (E. coli LT-IIa-B(5)/IIb-B(5)) }\end{array}$ & $\begin{array}{c}\text { enterohemorragic E. coli }[106,107], \\
\text { Lyme Disease }[108,109] \\
\text { Malaria [110,111], HBV [112,113] } \\
\text { HIV [114,115],Chlamydia }[116], \\
\text { Salmonella [117], Neisseriae [118,119], } \\
\text { Influenza [120,121], Helminths [122], } \\
\text { F. tularensis [123] }\end{array}$ & $\begin{array}{c}\text { LYMErix [109] } \\
\text { Theradigm-HBV [112] }\end{array}$ \\
\hline TLR5 & Flagellin & $\begin{array}{c}\text { Y.pestis [124], West Nile virus [125], } \\
\text { L. monoctyogenes [126], Malaria [127,128], } \\
\text { Dental Caries [129], Cancer [130,131], } \\
\text { HPV [131], Influenza }[132-138]\end{array}$ & $\begin{array}{c}\text { VAX128 }[134], \\
\text { VAX125 [135], } \\
\text { VAX102 [137], } \\
\text { STF2.4xMe [138] }\end{array}$ \\
\hline
\end{tabular}


Poly I:C12U (Ampligen $\left.{ }^{\circledR}\right)$, a synthetic Poly I:C containing mismatched bases (uracil and guanine), is also immunostimulatory while less toxic than Poly $\mathrm{I}: \mathrm{C}$ and Poly I:CLC. Intranasal immunization with Poly I:C12U as an adjuvant in a hemagglutinin (HA)-based H5N1 influenza vaccine induces higher levels of protective, specific mucosal IgA and systemic IgG responses than the corresponding adjuvant-free vaccine [53]. In phase II and III clinical trials for HIV vaccines, and in phase I and II cancer vaccine studies, Poly I:C12U has been deemed safe to use and induces maturation of mDCs, secretion of IL-12 and inhibition of IL-10, enhances antigen-specific CTL responses and Th1-type $\mathrm{CD}^{+} \mathrm{T}$ cell responses [54,139].

Poly I:C has also been combined with a cationic adjuvant formulation, CAF01, a liposome-based adjuvant composed of dimethyldioctadeclammonium and trehalose-6,6-dibehenate (DDA/TDB) [140]. The combined Poly I:C-CAF01 adjuvant is called CAF05. Through the effect of Poly I:C, CAF05 enhances $\mathrm{CD}^{+} \mathrm{T}$ cell responses and, through the effect of CAF01, induces a long lasting antigen depot. CAF05 favors Th1-type and Th17-type immunity and antibody responses in animal models of bacterial, viral and parasitic infections, and also has an effect on reducing tumor growth rates [52,141].

\subsection{TLR4-Dependent Adjuvants}

TLR4 (CD284) is expressed by the majority of circulating immune cells but its mature form has been characterized in macrophages and mDCs [37,142]. TLR4 signals via both the MyD88-dependent and the (MyD88-independent) TRIF-dependent pathway, leading to a robust IL-12 production, secretion of type I IFNs and a strong Th1-type cellular and humoral immune response (Figure 1).

A number of TLR4 ligands has been described, with lipopolysaccharide (LPS) being the first bacterial product shown to interact with this receptor [143]. Other TLR4 agonists include a variety of components from fungi, viruses and parasites and endogenous ligands [144-147]. The TLR4/LPS molecular interaction has been elucidated in detail [148]. LPS has a hydrophilic polysaccharide component and a hydrophobic lipid A, composed of polyacylated diglucosamine lipids. The lipid A interacts with the TLR4 accessory molecule, lipid A binding protein (LBP) [149], followed by formation of a complex with CD14 (soluble or cell wall-anchored via glycosyl-phosphatidylinositol (GPI)), which is then presented to TLR4 and the myeloid differentiation protein 2 (MD-2) [150].

LPS, along with its molecular derivatives, has been tested in numerous vaccine clinical trials (Table 1). However, despite its strong immunostimulatory effect, an intrinsic toxicity severely limits its use in humans. A detoxified form of LPS, the monophosphoryl lipid A (MPLA) from Salmonella minnesota R595, was developed by Ribi [151]. MPLA retains a potent immunostimulatory activity in vitro and in vivo while lacking toxicity, and is used in a number of complex adjuvants broadly referred to as Ribi adjuvant systems (RAS). For example, synthetic MPL RC-529 (Ribi.529) is used in the human hepatitis B virus (HBV) recombinant antigen vaccine, SupervaxTM [55]. MPLA triggers both the MyD88-dependent and TRAM/TRIF-dependent pathway, although an apparent preferential bias towards signaling via the TRIF-dependent pathway has been reported [152]. Induction of a strong protective Th1-biased immunity and secretion of pro-inflammatory mediators (i.e., TNF- $\alpha$ ) by MPLA has been shown for Leishmania and TB vaccine formulations, as well as induction of anti-inflammatory mediators (i.e., IL-10) [61,70]. 
MPLA has been combined with a variety of other adjuvants, such as QS21 and liposomes (AS01, GlaxoSmithKline (GSK) Vaccines), QS21 and an oil-in-water emulsion (AS02 (GSK)), and alum (AS04 (GSK)) [153] (Table 1). Due to the effect of MPLA, AS01, AS02 and AS04 all induce TLR4-dependent NF- $\mathrm{BB}$ activity and cytokine secretion, maturation and trafficking of DCs and monocytes to the draining lymph nodes and antigen-specific T cell activation (although AS04 does not directly activate $\mathrm{B}$ or $\mathrm{CD} 4{ }^{+} \mathrm{T}$ lymphocytes) [154].

In experimental and clinical trials, AS01 has been shown to induce Th1-type immunity, improve $\mathrm{CD}^{+} \mathrm{T}$-cell responses and high antibody titers, for example to TB, varicella zoster virus (VZV), HIV antigens and to the malaria antigen RTS,S (a P. falciparum surface protein fused to the HBV surface antigen (HBsAg)) $[63,64,68]$. AS02, which has also been tested with HBV, HIV, TB and malaria antigens, elicits a more balanced Th1/Th2 immunity, with lower lymphoproliferative responses and a shorter-lived protection than AS01 [62,65,68]. By contrast, AS02 induces higher CD8 ${ }^{+}$cytolytic T cell responses than AS04, the MPLA/alum adjuvant. In the AS04 adjuvant, the MPLA/antigen complex is stabilized by the presence of alum, which also favors formation of antigen depot. AS04-containing vaccines have been tested against viral pathogens, including HBV [57], HPV [70,71], herpes simplex virus (HSV) [74] and Epstein-Barr virus (EBV) [75] showing improved protective responses than the corresponding alum-alone containing vaccines. AS04 is part of the HBV vaccine, FENDrix ${ }^{\circledR}$ [58], which has been safely and successfully used in healthy adults and in specific high-risk patients $[55,59]$. The AS04-containing vaccine against HPV, Cervarix ${ }^{\circledR}$, is prophylactically used against cervical cancer and is also well tolerated [72,73]. In addition, MPLA-containing adjuvants have been used in cancer vaccine formulations, for example with the MUC1 antigen against prostate cancer or non-small cell lung cancer (NSCLC) [78] (Stimuvax ${ }^{\circledR}$ ), or in combination with the adjuvant DETOX ${ }^{\circledR}$ (an oil-droplet complex that contains purified Mycobacterium phlei cell wall skeleton products (CWS) [76]) in a melanoma vaccine (Melacine $\left.{ }^{\circledR}\right)$. DETOX is also used with the MUC1/ KLH antigen complex (Theratope) in breast and ovarian cancer treatment [79]. AS02 has also been used with the recombinant melanoma-associated antigen 3 (MAGE-A3) in cancer vaccine approaches, with some success [77]. The AS01, AS02 and AS04-adjuvanted vaccines are considered safe [66,67,69].

Based on the success of AS04, and on the different chemical composition of MPLA species, the adjuvant effect of other synthetic lipid A mimetics with different length and degree/type of fatty acid acylation has been examined (Table 1). For example, aminoalkyl glucosaminide 4-phosphates (AGPs), tested against L. monocytogenes, influenza and RSV [81], the E6020 synthetic molecule [155], and the RC-529 (Ribi.529) molecule, structurally similar to the hexa-acyl component of MPL® [65]. These synthetic lipid A mimetics are considered safe. Another synthetic lipid A derivative, glycopyranosyl lipid adjuvant (GLA) has been used in combination with squalene (SE, an oil-in-water emulsion), and shown to induce strong Th1-type responses, enhance antigen-specific responses and have a good safety profile [82]. Lastly, the lipid A derivative, OM-174 from E. coli, has also been tested for its adjuvant effect [80].

\subsection{TLR7- and TLR8-Dependent Adjuvants}

TLR7 and TLR8 (CD288) are expressed in neutrophils, monocytes, macrophages, eosinophils and B cells (TLR7), plasmacytoid DCs (pDCs) (TLR7), NK cells and T cells (TLR8) and Langerhans 
cells [156]. Similar to TLR3, TLR7 and TLR8 have an intracellular localization within endosomal compartments in the cells that express these receptors. Engagement of TLR7 and TLR8 leads to signaling through MyD88 Mal, NF- $\mathrm{KB}$ and IRF7 activation and secretion of proinflammatory cytokines, chemokines and other mediators (Figure 1). In DCs, TLR7/TLR8 activation leads to cell maturation/activation, expression of co-stimulatory molecules (CD80, CD86 and CD40), enhanced antigen presentation and secretion of Th1-type pro-inflammatory cytokines (IFN- $\alpha$, TNF- $\alpha$ and IL-12). pDCs respond to TLR7 activation by secreting IFN- $\alpha$ while mDCs respond to TLR8 activation by producing IL-12 [157]. Both TLR7 and TLR8 induce Langerhans cell differentiation and migration from the skin to the lymph nodes. Signaling via TLR7 induces secretion of Ig, IL-6 and TNF- $\alpha$ by B cells [158] and IFN- $\gamma$ by NK cells [159]. TLR8 signaling induces T cell proliferation, IFN- $\gamma$, IL-2 and IL-10 production, memory $\mathrm{T}$ cell activation and also reduces $\mathrm{CD}^{+}{ }^{+}$Treg-mediated immunosuppression [160].

The ligands for TLR7 and TLR8 include single stranded (ss) RNA enriched for poly-U or poly-GU sequences [161], synthetic imidazoquinolinamines, such as imiquimod (R-837) and resiquimod (R-848) [162] and guanosine analogues, such as loxoribine. While TLR7 or TLR8 agonists are not approved as vaccine adjuvant components, imiquimod and resiquimod have undergone extensive clinical testing in a 5\% cream formulation (AldaraTM) for topical treatment of HPV-induced warts, actinic keratoses, basal cell and squamous cell carcinoma, lentigo maligna and molluscum contagiosum $[83,84]$ (Table 1). Both compounds induce strong local secretion of IFN- $\alpha$, TNF- $\alpha$, IL-6 and IL-12, as well as cytotoxic T-cell responses. Topical application of imiquimod-containing formulations has also been tested in prostate cancer vaccines, favoring development of specific CTL responses and antibodies [85]. In a melanoma trial, systemic co-administration of imiquimod, a melanoma peptide vaccine and Flt-3 ligand (a DC activator) resulted in enhanced peptide immunogenicity and recruitment of both $\mathrm{mDCs}$ and $\mathrm{pDCs}$ in the treated areas. Imiquimod topical application also favors development of a $\mathrm{T}$ cell-dependent response to intradermal injection of the melanoma antigen, NY-ESO-1 [87]. In various tumor animal models, the combination of DNA-based vaccines and imiquimod treatment has been successful in reducing tumor onset, increasing CTL responses and IgG2a antibody production [86]. In pre-clinical studies on HSV and HIV, antigen-specific T cell responses and antibody secretion are enhanced by imiquimod [88], and in Leishmania infections, macrophage-dependent bacterial killing and resolution of cutaneous lesions have been reported following use of imiquimod [89]. Unfortunately, systemic administration of imiquimod is highly toxic and studies on TLR7/TLR 8 adjuvant safety and efficacy are limited by the unresponsiveness of mice to TLR8 agonists for human use [161].

\subsection{TLR9-Dependent Adjuvants}

In humans, TLR9 (CD289) is expressed by immune cells in intracellular endosomal compartments and its role is particularly relevant in B cells and pDCs [163]. TLR9 signals through the MyD88 pathway via IRAK and TRAF-6 without the contribution of Mal (Figure 1), leading to production of Th1-type pro-inflammatory cytokines (IL-1, IL-6, IL-12, IL-18, TNF- $\alpha$ and IFN- $\gamma$ ), up-regulation of CD80, CD86, CD40 and MHC molecules expression, increased antigen processing/presentation and $\mathrm{CD}^{+} \mathrm{T}$ cell responses [164,165]. In particular IL-12 and type I IFNs induced in pDCs via TLR9 drive 
a strong Th1-type immunity and CD8 ${ }^{+}$CTL cytotoxicity, while TLR9-dependent B cell activation leads to increased antigen-specific humoral responses and IgG class switching [166,167].

The ligands for TLR9 are bacterial and viral DNA that contains unmethylated CpG motifs and synthetic oligodeoxynucleotides (ODN) expressing CpG motifs [168]. The synthetic TLR9 ligands retain the immunostimulatory activity of bacterial DNA and are divided in three major classes, based on their structure, biological properties and ability to activate immune cells in vitro $[169,170]$. Multiple CpG motifs on a phosphorothioate backbone are classified as "K" type ODN (also called "B" type), which are strong inducers of B cell activation, pDCs and monocyte maturation. "D" type ODN (also called "A" type), have a mixed phosphodiester/phosphothioate backbone containing a single CpG motif flanked by palindromic sequences and 3'- and 5'-end poly-G tails that allow formation of concatamers. These CpG ODN activate NK cells. The third category, "C" type ODN, is structurally and functionally similar to both "K" type and "D" type ODN, with both phosphorothioate nucleotides and palindromic CpG motifs, and induce activation of both B cells and pDCs and production of IFN- $\alpha$.

Numerous pre-clinical and clinical studies have been carried out with TLR9 adjuvants (Table 1) [171,172]. The adjuvant activity of "K" type ODN has been explored in vaccine models against malaria [90,91], HBV [94,95], influenza [93] and anthrax [98]. CpG ODN induces a strong specific antibody response to the malarial Apical Membrane Antigen 1 (AMA1) and to the merozoite surface protein 142 (MSP142) (both poorly immunogenic vaccine candidates) [92]. In the case of $\mathrm{HBV}$, the B type CpG ODN, CPG 7909, enhances specific, long-term antibody responses to the Engerix-B ${ }^{\circledR}$ vaccine (recombinant $\mathrm{HBsAg}$ vaccine absorbed on alum (Alhydrogel)), as compared to Engerix-B alone [96]. Another CpG ODN, the 1018 immunostimulatory sequence (ISS), has shown to improve the efficacy of the HBV vaccine Heplisav ${ }^{\circledR}$, with only minor local side effects [97]. By contrast, inclusion of $\mathrm{CpG} 7909$ in the influenza vaccines Fluarix ${ }^{\circledR}$ is considered less substantial, although it enhances IFN- $\gamma$ secretion and is well tolerated, which is advantageous for reducing the vaccine dosage [93].

CpG-ODN is also used in anti-cancer vaccines and immunotherapy, due to its ability to induce high numbers of tumor-specific cytotoxic $\mathrm{CD}^{+} \mathrm{T}$ cells when co-administered with HPV and melanoma tumor antigens $[99,100]$. In vaccine trials with the synthetic tumor peptide MART1 (melanoma-associated antigen recognized by T cells 1) (Melan-A) and with the NY-ESO-1 peptide antigen, addition of CpG ODN enhances antigen-specific $\mathrm{CD}^{+} \mathrm{T}$ cell responses [101,104]. CpG 7909 has only shown partial success when used in a MAGE-A3 protein-based vaccine, which has been improved by addition of MPL and QS21 in a liposomal formulation to CpG 7909, the AS15 adjuvant. The AS15-adjuvanted vaccine induces an increased MAGE-A3 delivery to APCs and enhances T-cell immunogenicity [105] (Table 1). However, despite a good safety profile of CpG 7909, intra-tumoral injection of this TLR9 adjuvant has shown scarce results on tumor growth in melanoma and basal cell carcinoma models [102]. Similarly, evaluation of CpG 7909 administration during chemotherapy for NSCLC treatment, or combined with GM-CSF and the tumor antigen, hTERT (human telomerase reverse transcriptase), has not shown a great success rate [103]. 


\section{TLR Adjuvants with a Preferential Th2-bias}

\subsection{TLR2-Dependent Adjuvants}

TLR2 (CD282) expression is relatively ubiquitous in immune cells and is found on the surface of neutrophils, macrophages, monocytes, basophils, T cells, B cells, NK cells and immature DCs [37]. TLR2 dimerizes with either TLR1 or TLR6 and also utilizes other accessory molecules, such as CD36, CD14 and LBP [173-176]. TLR2-dependent signaling proceeds through the Mal/TIRAP and MyD88-dependent pathway, inducing activation of NF- $\mathrm{BB}$ and MAPKs pathways leading to immune cell activation, survival/proliferation, secretion of inflammatory mediators and expression of co-stimulatory molecules (CD80, CD86 and CD40) (Figure 1).

TLR2 interacts with structurally diverse ligands. Natural and synthetic lipopeptides and lipoproteins that signal via TLR2 include $M$. fermentans macrophage-activating lipopeptide (MALP-2), a TLR2/TLR6 ligand [173], the syntetic triacylated lipoprotein, Pam3CSK4, a TLR2/TLR1 ligand [174] and the diacylated lipoprotein, Pam2CSK4, a TLR2/TLR6 ligand [177]. TLR2 also binds peptidoglycans (PG) [178], glycosylphosphatidyl-inositol-anchored structures from gram positive bacteria (lipoteichoic acid, LTA), lipo-arabinomannan from Mycobacteria and lipomannas from M. tuberculosis [179]) and other cell wall components (i.e., $\beta$-glucans [180] and zymosan [181]), as well as viral products [182] and some bacterial LPS types (reviewed in the TLR4 section). Endogenous ligands and DAMPs [183] and several lipid-free bacterial proteins have also been described as TLR2 ligands, including porins, toxins, fimbriae [184] and the PPE18 protein from M. tuberculosis [185]. The molecular and structural details of TLR2 interaction with some of its ligands have been elucidated, while other TLR2/agonist complexes are currently being explored [186-188].

The adjuvanticity of TLR2 agonists has been characterized as predominantly Th2-biased. The most extensively studied TLR2 adjuvants include MALP-2, Pam3CSK4, Neisseria PorB and E. coli LT-IIa-B(5) and LT-IIb-B(5) (Table 1). A large majority of studies conducted with these adjuvants have been carried out in experimental animal models, and most are not yet approved for routine administration in humans. In experimental and pre-clinical studies, TLR2 adjuvants support DC and B cell responses and $\mathrm{T}$ cell activation, including that of antigen-specific $\mathrm{CD}^{+} \mathrm{T}$ cell (CTL), although at relatively modest levels as compared to other TLR adjuvants [189]. Treg functions can also be influenced by TLR2 activation; for example, TLR2/TLR1 signaling may mediate protective mucosal Th17-type responses to pathogens and Treg cells expansion, while TLR2/TLR6 signaling may promote tolerogenic dendritic cells and Treg responses [190].

MALP-2 has been used as an adjuvant in a number of experimental immunization studies with prototype antigens, such as ovalbumin (OVA), but also in disease models. Intranasal administration of MALP-2 in a vaccine model against enterohemorragic $E$. coli enhances secretion of antigen-specific serum IgG and mucosal IgA, IFN- $\gamma$, IL-2 and IL-4 [106]. The synthetic derivative of MALP-2, BPP ( $S$-[2,3-bispalmitoyiloxy-(2R)-propyl]- $R$-cysteinyl-amido-monomethoxyl polyethylene glycol), also enhances secretion of antigen-specific antibodies and cytokines (TNF- $\alpha$, IL-10 and MIP-1 $\beta$ ), and favors antigen cross-presentation by DCs to $\mathrm{CD}^{+} \mathrm{T}$ cells and cytotoxic T-cell response [191].

Lipoproteins have been also used in experimental and clinical vaccine studies. In a vaccine against Lyme disease, immunization with the B. burgdorferi outer surface lipoprotein A (OspA) with alum has 
shown enhanced secretion of protective antibodies against a C-terminus epitope of OspA [108]. This Lyme disease vaccine, LYMErix ${ }^{\circledR}$, was licensed in 1998 after showing a good safety profile in clinical trials. However, potential concerns regarding skewing of Treg responses toward a Th17 phenotype and induction of autoimmune disease have stopped its commercialization [109]. Pam3CSK4 has been used in an anti-malarial vaccine containing several $P$. falciparum circumsporozoite protein (CSP) B cell epitopes and a universal $\mathrm{T}$ cell epitope, demonstrating induction of relatively high titers of peptide-specific IgG and IgG1, IgG3 and IgG4 antibody subclasses in immunized volunteers [110]. Lipid-containing TLR2 adjuvants can be easily conjugated to vaccine antigens, and even antigens themselves can be modified by addition of a lipid-core peptide for TLR2 interaction and direct activation of immune cells [192]. Such a strategy has been employed in a vaccine containing an HBV core antigen CTL peptide and a helper T lymphocyte (HTL) peptide conjugated with a palmitic acid at the N-terminus (Theradigm-HBV) [112]. In a phase I trial, this vaccine has shown higher immunogenicity than the un-palmitoylated vaccine and induction of long-term, dose-dependent, HBV-specific CTL responses in healthy subjects [113]. Phase I and II trials of an HIV-1 lipopeptide-based vaccine have shown similar long-lived, antigen-specific IgGs and specific CTL responses [114].

Porins from Neisseriae, F. nucleatum, Chlamydia, Shigella, Haemophilus and Salmonella have been examined in numerous experimental immunization and pathogen challenge models. Generally, bacterial porins have a rather conserved, trimeric structure consisting of monomers with a high content of $\beta$-barrel structure. In the bacterial membrane, porins mediate passage of ions and solutes for organism survival [193]. Purified porins can be formed into stable native preparations, called proteosomes, and are recognized by TLR2 on the surface of immune cells. Porins from Neisseriae, F. nucleatum and Chlamydia have a TLR2/TLR1-dependent adjuvant activity [194-196], while the adjuvanticity of Shigella porin and Salmonella OmpS2 is mediated by TLR2/TLR6 signaling [117,197]. Remarkably, Neisseria, F. nucleatum, Chlamydia and Salmonella porins induce Th2-type skewed immune responses [116,173,195] while Shigella porin appears to favor Th1-type responses [198]. The TLR2-dependent porin effects include APC activation/proliferation, increased surface expression of CD80 (Shigella, Salmonella), CD86 (Neisseria, F. nucleatum, Chlamydia), CD40 and MHC II molecules and induction of antigen-specific IgM, IgG and IgA antibodies [118,119,196,199,200]. Neisserial porin proteosomes have been tested as adjuvants in mucosal and systemic vaccinations against different pathogens in both experimental and clinical models without side effects or toxicity [111,120-123,201].

Toxins from Enterobacteriacee, divided in type I (the cholera toxin (CT) and the E. coli heat-labile enterotoxin I (LT-I)) and type II (the E. coli LT-IIa, LT-IIb and LT-IIc) [202-204], are also potent mucosal immune adjuvants, although their clinical development is severely compromised by their high toxicity in humans [205]. Enterotoxins are oligomeric proteins composed of an A subunit, responsible for the enzymatic activity of the toxin, and a pentameric B subunit (B5), which mediates binding to ganglioside receptors on host cells (i.e., GM1, GD1b and GD1a, GQ1 and GT1). Genetically detoxified type I toxin A and B subunits, including the LTK63, LTR192G, LTR72 and LTH44A molecules, have been tested in experimental vaccine models against bacterial, viral and parasitic infections, in cancer vaccines and in clinical trials [107,115,206,207], but their safety remains under scrutiny [208]. Besides binding to ganglioside receptors, the B subunit of type II LT (LT-IIa-B(5) and LT-IIb-B(5)) also binds to TLR2 [209,210], via regions that are normally masked by the A subunit in 
the whole holotoxin [209]. Interaction of LT-IIa-B(5) and LT-IIb-B(5) with the TLR2/TLR1 heterodimer is facilitated by binding to the GDla ganglioside and leads to APC activation, secretion of high levels of antigen-specific systemic and salivary IgG and IgA antibodies, memory B cell development, secretion of cytokines (with high IL-4 and low IL-12), repression of Treg development/function and increased Th1, Th17 and especially Th2-type responses [204,210-212]. Additionally, LT-IIa induces CD8 ${ }^{+}$ $\mathrm{T}$ cell apoptosis, thereby reducing IFN- $\gamma$ secretion and further influencing Th-type immunity [213]. The TLR2-dependent functions are retained by non-toxic mutants of the LT B(5) subunit, such as LT-IIb(T13I), which fail to bind their ganglioside receptors [214,215].

\subsection{TLR5-Dependent Adjuvants}

TLR5 is expressed on the surface of neutrophils, monocytes, mDCs, Langerhans cells, T cells and NK cells [163,216,217]. Signaling through TLR5 via the MyD88 Mal pathway leads to a strong induction of NF- $\kappa \mathrm{B}$ activation and a preferential Th2-type immunity (although a Th1 component can be also present) [218,219] (Figure 1). The ligand for TLR5 is bacterial flagellin and the TLR5-binding region is located in a conserved region of flagellin, the D1 portion [220-224]. A number of experimental models have demonstrated that flagellin, in both soluble monomeric and polymeric forms, has an immune adjuvant effect and induces DC maturation/activation with subsequent up-regulation of CD80, CD83, CD86 and MHC class II, secretion of IL-10 and TNF- $\alpha$ by monocytes and IFN- $\gamma$ and $\alpha$-defensins by NK cells, T cell proliferation/activation and antigen-specific CTL responses [224,225]. Although likely not through a direct effect on B cells, but more to a general TLR5-dependent enhancement of APC functions, immunization with flagellin-containing vaccines also leads to enhanced secretion of antigen-specific IgG and local IgA responses [222]. For example, addition of flagellin in an intranasal influenza vaccine in mice has shown enhancement of immune response as compared to the vaccine without flagellin [133,134]. Similar effects have been shown in experimental models of vaccination against $Y$. pestis [124], West Nile virus [125] and L. monocytogenes [216] (Table 1).

A major advantage of this TLR5-dependent adjuvant is its use in fusion proteins with recombinant antigens, which has shown induction of superior immune responses as compared to simultaneous co-administration of flagellin and antigens $[19,127,226]$. This approach has been used in experimental and clinical trials of vaccines against influenza, using a flagellin/hemagglutinin-based vaccine (VAX125, VAX128) [134-136] or a flagellin/matrix protein 2 ectodomain (M2e) vaccine (VAX102) [137,138], and in vaccines against malaria [127,128], vaccinia virus [227], P. aeruginosa [228] and even against dental caries [129]. Although the safety of flagellin-based vaccines is still being evaluated in clinical trials, no major local or systemic side effects have been reported so far.

In addition to its use as adjuvant for vaccines against infectious diseases, flagellin has also been used in cancer treatment, where NF-kB and transcriptional regulation of mediators of apoptosis are induced by flagellin via TLR5 signaling. It is thought that reduction of apoptotic cell death may be beneficial for the consequences of radiation treatment in normal tissues. In experimental irradiation studies in rodents and primates, improved survival rates have been observed following vaccination with flagellin-derived polypeptide (CBLB502) [130]. In other studies on potential anti-cancer strategies, flagellin has also shown an enhanced generation of tumor-specific $\mathrm{CD}^{+} \mathrm{T}$ cell immune responses [131]. 


\section{Conclusions}

The ultimate goal of vaccination is to generate protection against diseases. Such protective immunity requires induction of different host responses that are elicited by using vaccine formulations containing appropriate antigens and adjuvants. Adjuvants are important components of vaccines and can influence the outcomes of vaccination, particularly by directing host immune responses towards different $\mathrm{T}$ helper cell immunity and enhancing both the quality and the quantity of immune response against the antigens. However, major concerns in vaccine adjuvants development include their safety and efficiency. Even though vaccine design is still rather empirical, recent advances in immunology research have expanded our understanding of the mechanisms of action of various adjuvants and greatly improved the chances for successful development of safe and effective interventions to prevent and treat a number of human diseases through modulation of host immune responses. The discovery of TLRs and their role in modulation of innate and adaptive immunity has led to exploitation of their ligands as immune modulators, due to their ability to induce specific immune cell activation and influence host adaptive immunity. The advantage of TLR adjuvants is not only in their ability to preferentially induce Th1 or Th2 responses and development of $\mathrm{CD}^{+}$or $\mathrm{CD} 8^{+} \mathrm{T}$-cells, but also to modulate B cell activation and enhance antibody secretion to otherwise poorly immunogenic antigens, improving both quality and quantity of specific antibody production. Furthermore, TLR adjuvants appear suitable for enhancing mucosal immunity, an area that is gravely underdeveloped in the current human vaccine strategies.

As discussed here, experimental models and clinical trials evaluating TLR agonists as immune adjuvants have identified valuable molecules for use in vaccines against infectious diseases, allergies and cancer immunotherapy (Table 1). In particular, TLR3, TLR4 and TLR9 agonists have been shown to improve a number of vaccines, for example against HBV, influenza, malaria and anthrax, as well as some types of cancer. TLR7/TLR8 agonists are less developed as adjuvants but are already used with success in topical cancer immunotherapy. The efficacy of vaccine formulations containing traditional adjuvants has also been reported to be synergistically improved by the addition of TLR agonists. It is likely that the known TLR ligands described here and potentially other novel TLR ligands with adjuvant effect, could be introduced in human vaccine formulations worldwide in the near future as both stand-alone adjuvant systems or in combination with existing non-TLR adjuvants in the design of next-generation vaccines $[19,126,229]$.

\section{Acknowledgements}

The authors thank Lee M. Wetzler and Munir Mosaheb (Boston University) for critically reading the manuscript, and NIH/NIAID grant R01 AI40944.

\section{Author Contribution}

Deana N. Toussi and Paola Massari contributed towards writing of the manuscript.

\section{Conflicts of Interest}

The authors declare no conflict of interest. 


\section{Reference}

1. Gupta, R.K.; Relyveld, E.H.; Lindblad, E.B.; Bizzini, B.; Efraim, S.B.; Gupta, C.K. Adjuvants-A balance between toxicity and adjuvanticity. Vaccine 1993, 11, 293-306.

2. Singh, M.; Srivastava, I. Advances in vaccine adjuvants for infectious diseases. Curr. HIV. Res. 2003, 1, 309-320.

3. Guy, B. The perfect mix: Recent progress in adjuvant research. Nat. Rev. Microbiol. 2007, 5, 505-517.

4. Glenny, A.T. Immunological notes: Antigenic value of toxoid precipitated by potassium alum. J. Pathol. Bacteriol. 1926, 29, 38-39.

5. Freund, J. The mode of action of immunologic adjuvants. Bibl. Tuberc. 1956, 10, 130-148.

6. Calabro, S.; Tritto, E.; Pezzotti, A.; Taccone, M.; Muzzi, A.; Bertholet, S.; de Gregorio, E.; O'Hagan, D.T.; Baudner, B.; Seubert, A. The adjuvant effect of MF59 is due to the oil-in-water emulsion formulation, none of the individual components induce a comparable adjuvant effect. Vaccine 2013, 31, 3363-3369.

7. Hutchison, S.; Benson, R.A.; Gibson, V.B.; Pollock, A.H.; Garside, P.; Brewer, J.M. Antigen depot is not required for alum adjuvanticity. FASEB J. 2012, 26, 1272-1279.

8. Seubert, A.; Calabro, S.; Santini, L.; Galli, B.; Genovese, A.; Valentini, S.; Aprea, S.; Colaprico, A.; D’Oro, U.; Giuliani, M.M.; et al. Adjuvanticity of the oil-in-water emulsion MF59 is independent of Nlrp3 inflammasome but requires the adaptor protein MyD88. Proc. Natl. Acad. Sci. USA 2011, 108, 11169-11174.

9. Janeway, C.A., Jr. Immunogenecity: Signal 1,2,3...and 0. Immunol. Today 1989, 10, $283-287$.

10. Awate, S.; Babiuk, L.A.; Mutwiri, G. Mechanisms of action of adjuvants. Front. Immunol. 2013, 4, doi:10.3389/fimmu.2013.00114.

11. Mosmann, T.R.; Cherwinski, H.M.; Bond, M.W.; Giedlin, M.A.; Coffman, R.L. Two types of murine helper $\mathrm{T}$ cell clones.I. Definition according to the profiles of lymphokine activity and secreted proteins. J. Immunol. 1986, 136, 2348-2357.

12. Harrington, L.E.; Mangan, P.R.; Weaver, C.T. Expanding the effector CD4 T-cell repertoire: The Th17 lineage. Curr. Opin. Immunol. 2006, 18, 349-356.

13. Ouyang, W.; Kolls, J.K.; Zheng, Y. The biological functions of T helper 17 cell effector cytokines in inflammation. Immunity 2008, 28, 454-467.

14. Buck, S.B.; Bradford, J.; Gee, K.R.; Agnew, B.J.; Clarke, S.T.; Salic, A. Detection of S-phase cell cycle progression using 5-ethynyl-2'-deoxyuridine incorporation with click chemistry, an alternative to using 5-bromo-2'-deoxyuridine antibodies. Biotechniques 2008, 44, 927-929.

15. Kumar, P.; Chen, K.; Kolls, J.K. Th17 cell based vaccines in mucosal immunity. Curr. Opin. Immunol. 2013, 25, 373-380.

16. Brewer, J.M.; Conacher, M.; Hunter, C.A.; Mohrs, M.; Brombacher, F.; Alexander, J. Aluminium hydroxide adjuvant initiates strong antigen-specific Th2 responses in the absence of IL-4- or IL-13-mediated signaling. J. Immunol. 1999, 163, 6448-6454.

17. Medzhitov, R.; Preston-Hurlburt, P.; Janeway, C.A., Jr. A human homologue of the Drosophila Toll protein signals activation of adaptive immunity. Nature 1997, 388, 394-397. 
18. Kaisho, T.; Akira, S. Toll-like receptors as adjuvant receptors. Biochim. Biophys. Acta 2002, 1589, 1-13.

19. Duthie, M.S.; Windish, H.P.; Fox, C.B.; Reed, S.G. Use of defined TLR ligands as adjuvants within human vaccines. Immunol. Rev. 2011, 239, 178-196.

20. Gnjatic, S.; Sawhney, N.B.; Bhardwaj, N. Toll-like receptor agonists: Are they good adjuvants? Cancer J. 2010, 16, 382-391.

21. Jin, B.; Sun, T.; Yu, X.H.; Yang, Y.X.; Yeo, A.E. The effects of TLR activation on T-cell development and differentiation. Clin. Dev. Immunol. 2012, 2012,. doi:10.1155/2012/836485.

22. Conroy, H.; Marshall, N.A.; Mills, K.H. TLR ligand suppression or enhancement of Treg cells? A double-edged sword in immunity to tumours. Oncogene 2008, 27, 168-180.

23. Keijzer, C.; van der Zee, R.; van, E.W.; Broere, F. Treg inducing adjuvants for therapeutic vaccination against chronic inflammatory diseases. Front. Immunol. 2013, 4, doi:10.3389/fimmu.2013.00245.

24. Akira, S.; Hemmi, H. Recognition of pathogen-associated molecular patterns by TLR family. Immunol. Lett. 2003, 85, 85-95.

25. Cario, E.; Brown, D.; McKee, M.; Lynch-Devaney, K.; Gerken, G.; Podolsky, D.K. Commensal-associated molecular patterns induce selective toll-like receptor-trafficking from apical membrane to cytoplasmic compartments in polarized intestinal epithelium. Am. J. Pathol. 2002, 160, $165-173$.

26. Matzinger, P. Tolerance, danger, and the extended family. Annu. Rev. Immunol. 1994, 12, 991-1045.

27. Medzhitov, R.; Preston-Hurlburt, P.; Kopp, E.; Stadlen, A.; Chen, C.; Ghosh, S.; Janeway, C.A., Jr. MyD88 is an adaptor protein in the hToll/IL-1 receptor family signaling pathways. Mol. Cell. 1998, 2, 253-258.

28. Fitzgerald, K.A.; Palsson-McDermott, E.M.; Bowie, A.G.; Jefferies, C.A.; Mansell, A.S.; Brady, G.; Brint, E.; Dunne, A.; Gray, P.; Harte, M.T.; et al. Mal (MyD88-adapter-like) is required for Toll-like receptor-4 signal transduction. Nature 2001, 413, 78-83.

29. Fitzgerald, K.A.; Rowe, D.C.; Barnes, B.J.; Caffrey, D.R.; Visintin, A.; Latz, E.; Monks, B.; Pitha, P.M.; Golenbock, D.T. LPS-TLR4 signaling to IRF-3/7 and NF-kB involves the toll adapters TRAM and TRIF. J. Exp. Med. 2003, 198, 1043-1055.

30. O’Neill, L.A.; Fitzgerald, K.A.; Bowie, A.G. The Toll-IL-1 receptor adaptor family grows to five members. Trends Immunol. 2003, 24, 286-289.

31. Muzio, M.; Ni, J.; Feng, P.; Dixit, V.M. IRAK (Pelle) family member IRAK-2 and MyD88 as proximal mediators of IL-1 signaling. Science 1997, 278, 1612-1615.

32. Gohda, J.; Matsumura, T.; Inoue, J. Cutting edge: TNFR-associated factor (TRAF) 6 is essential for MyD88-dependent pathway but not toll/IL-1 receptor domain-containing adaptor-inducing IFN-beta (TRIF)-dependent pathway in TLR signaling. J. Immunol. 2004, 173, 2913-2917.

33. Meylan, E.; Burns, K.; Hofmann, K.; Blancheteau, V.; Martinon, F.; Kelliher, M.; Tschopp, J. RIP1 is an essential mediator of Toll-like receptor 3-induced NF-kappa B activation. Nat. Immunol. 2004, 5, 503-507.

34. Shim, J.H.; Xiao, C.; Paschal, A.E.; Bailey, S.T.; Rao, P.; Hayden, M.S.; Lee, K.Y.; Bussey, C.; Steckel, M.; Tanaka, N.; et al. TAK1, but not TAB1 or TAB2, plays an essential role in multiple signaling pathways in vivo. Genes Dev. 2005, 19, 2668-2681. 
35. Honda, K.; Yanai, H.; Negishi, H.; Asagiri, M.; Sato, M.; Mizutani, T.; Shimada, N.; Ohba, Y.; Takaoka, A.; Yoshida, N.; et al. IRF-7 is the master regulator of type-I interferon-dependent immune responses. Nature 2005, 434, 772-777.

36. Oganesyan, G.; Saha, S.K.; Guo, B.; He, J.Q.; Shahangian, A.; Zarnegar, B.; Perry, A.; Cheng, G. Critical role of TRAF3 in the Toll-like receptor-dependent and -independent antiviral response. Nature 2006, 439, 208-211.

37. Muzio, M.; Polentarutti, N.; Bosisio, D.; Prahladan, M.K.; Mantovani, A. Toll-like receptors: A growing family of immune receptors that are differentially expressed and regulated by different leukocytes. J. Leukoc. Biol. 2000, 67, 450-456.

38. Liu, L.; Botos, I.; Wang, Y.; Leonard, J.N.; Shiloach, J.; Segal, D.M.; Davies, D.R. Structural basis of toll-like receptor 3 signaling with double-stranded RNA. Science 2008, 320, 379-381.

39. Alexopoulou, L.; Holt, A.C.; Medzhitov, R.; Flavell, R.A. Recognition of double-stranded RNA and activation of NF-kappaB by Toll-like receptor 3. Nature 2001, 413, 732-738.

40. Matsukura, S.; Kokubu, F.; Kurokawa, M.; Kawaguchi, M.; Ieki, K.; Kuga, H.; Odaka, M.; Suzuki, S.; Watanabe, S.; Homma, T.; et al. Role of RIG-I, MDA-5, and PKR on the expression of inflammatory chemokines induced by synthetic dsRNA in airway epithelial cells. Int. Arch. Allergy Immunol. 2007, 143, 80-83.

41. Salem, M.L.; Diaz-Montero, C.M.; El-Naggar, S.A.; Chen, Y.; Moussa, O.; Cole, D.J. The TLR3 agonist poly(I:C) targets $\mathrm{CD}^{+} \mathrm{T}$ cells and augments their antigen-specific responses upon their adoptive transfer into naive recipient mice. Vaccine 2009, 27, 549-557.

42. Nordlund, J.J.; Wolff, S.M.; Levy, H.B. Inhibition of biologic activity of poly I: poly C by human plasma. Proc. Soc. Exp. Biol. Med. 1970, 133, 439-444.

43. Schulz, O.; Diebold, S.S.; Chen, M.; Naslund, T.I.; Nolte, M.A.; Alexopoulou, L.; Azuma, Y.T.; Flavell, R.A.; Liljestrom, P.; e Sousa, C.R. Toll-like receptor 3 promotes cross-priming to virus-infected cells. Nature 2005, 433, 887-892.

44. Fujimoto, C.; Nakagawa, Y.; Ohara, K.; Takahashi, H. Polyriboinosinic polyribocytidylic acid [poly(I:C)]/TLR3 signaling allows class I processing of exogenous protein and induction of HIV-specific $\mathrm{CD}^{+}$cytotoxic T lymphocytes. Int. Immunol. 2004, 16, 55-63.

45. Trumpfheller, C.; Caskey, M.; Nchinda, G.; Longhi, M.P.; Mizenina, O.; Huang, Y.; Schlesinger, S.J.; Colonna, M.; Steinman, R.M. The microbial mimic poly IC induces durable and protective CD4 ${ }^{+}$ T cell immunity together with a dendritic cell targeted vaccine. Proc. Natl. Acad. Sci. USA 2008, 105, 2574-2579.

46. Scallan, C.D.; Tingley, D.W.; Lindbloom, J.D.; Toomey, J.S.; Tucker, S.N. An adenovirus-based vaccine with a double-stranded RNA adjuvant protects mice and ferrets against H5N1 avian influenza in oral delivery models. Clin. Vaccine Immunol. 2013, 20, 85-94.

47. Pulko, V.; Liu, X.; Krco, C.J.; Harris, K.J.; Frigola, X.; Kwon, E.D.; Dong, H. TLR3-stimulated dendritic cells up-regulate B7-H1 expression and influence the magnitude of CD8 T cell responses to tumor vaccination. J. Immunol. 2009, 183, 3634-3641.

48. Krown, S.E.; Kerr, D.; Stewart, W.E.; Field, A.K.; Oettgen, H.F. Phase I trials of poly(I,C) complexes in advanced cancer. J. Biol. Response Mod. 1985, 4, 640-649. 
49. Levy, H.B.; Baer, G.; Baron, S.; Buckler, C.E.; Gibbs, C.J.; Iadarola, M.J.; London, W.T.; Rice, J. A modified polyriboinosinic-polyribocytidylic acid complex that induces interferon in primates. J. Infect. Dis. 1975, 132, 434-439.

50. Butowski, N.; Chang, S.M.; Junck, L.; DeAngelis, L.M.; Abrey, L.; Fink, K.; Cloughesy, T.; Lamborn, K.R.; Salazar, A.M.; Prados, M.D. A phase II clinical trial of poly-ICLC with radiation for adult patients with newly diagnosed supratentorial glioblastoma: A North American Brain Tumor Consortium (NABTC01-05). J. Neurooncol. 2009, 91, 175-182.

51. Stahl-Hennig, C.; Eisenblatter, M.; Jasny, E.; Rzehak, T.; Tenner-Racz, K.; Trumpfheller, C.; Salazar, A.M.; Uberla, K.; Nieto, K.; Kleinschmidt, J.; et al. Synthetic double-stranded RNAs are adjuvants for the induction of $\mathrm{T}$ helper 1 and humoral immune responses to human papillomavirus in rhesus macaques. PLoS. Pathog. 2009, 5, e1000373.

52. Gram, G.J.; Karlsson, I.; Agger, E.M.; Andersen, P.; Fomsgaard, A. A novel liposome-based adjuvant CAF01 for induction of $\mathrm{CD}^{+}$cytotoxic T-lymphocytes (CTL) to HIV-1 minimal CTL peptides in HLA-A*0201 transgenic mice. PLoS One 2009, 4, e6950.

53. Ichinohe, T.; Kawaguchi, A.; Tamura, S.; Takahashi, H.; Sawa, H.; Ninomiya, A.; Imai, M.; Itamura, S.; Odagiri, T.; Tashiro, M.; et al. Intranasal immunization with $\mathrm{H} 5 \mathrm{~N} 1$ vaccine plus Poly I:Poly C12U, a Toll-like receptor agonist, protects mice against homologous and heterologous virus challenge. Microbes Infect. 2007, 9, 1333-1340.

54. Adams, M.; Navabi, H.; Jasani, B.; Man, S.; Fiander, A.; Evans, A.S.; Donninger, C.; Mason, M. Dendritic cell (DC) based therapy for cervical cancer: Use of DC pulsed with tumour lysate and matured with a novel synthetic clinically non-toxic double stranded RNA analogue poly [I]:poly [C(12)U] (Ampligen R). Vaccine 2003, 21, 787-790.

55. Dupont, J.; Altclas, J.; Lepetic, A.; Lombardo, M.; Vazquez, V.; Salgueira, C.; Seigelchifer, M.; Arndtz, N.; Antunez, E.; von Eschen, K.; et al. A controlled clinical trial comparing the safety and immunogenicity of a new adjuvanted hepatitis $\mathrm{B}$ vaccine with a standard hepatitis $\mathrm{B}$ vaccine. Vaccine 2006, 24, 7167-7174.

56. Tielemans, C.L.; Vlasak, J.; Kosa, D.; Billiouw, J.M.; Verpooten, G.A.; Mezei, I.; Ryba, M.; Peeters, P.C.; Mat, O.; Jadoul, M.Y.; et al. Immunogenicity and safety of an investigational AS02(v)-adjuvanted hepatitis B vaccine in patients with renal insufficiency who failed to respond or to maintain antibody levels after prior vaccination: results of two open, randomized, comparative trials. Vaccine 2011, 29, 1159-1166.

57. Kundi, M. New hepatitis B vaccine formulated with an improved adjuvant system. Expert Rev. Vaccines 2007, 6, 133-140.

58. Thoelen, S.; de Clercq, N.; Tornieporth, N. A prophylactic hepatitis B vaccine with a novel adjuvant system. Vaccine 2001, 19, 2400-2403.

59. Tong, N.K.; Beran, J.; Kee, S.A.; Miguel, J.L.; Sanchez, C.; Bayas, J.M.; Vilella, A.; de Juanes, J.R.; Arrazola, P.; Calbo-Torrecillas, F.; et al. Immunogenicity and safety of an adjuvanted hepatitis B vaccine in pre-hemodialysis and hemodialysis patients. Kidney Int. 2005, 68, 2298-2303.

60. Nascimento, E.; Fernandes, D.F.; Vieira, E.P.; Campos-Neto, A.; Ashman, J.A.; Alves, F.P.; Coler, R.N.; Bogatzki, L.Y.; Kahn, S.J.; Beckmann, A.M.; et al. A clinical trial to evaluate the safety and immunogenicity of the LEISH-F1+MPL-SE vaccine when used in combination with meglumine antimoniate for the treatment of cutaneous leishmaniasis. Vaccine 2010, 28, 6581-6587. 
61. Kathaperumal, K.; Park, S.U.; McDonough, S.; Stehman, S.; Akey, B.; Huntley, J.; Wong, S.; Chang, C.F.; Chang, Y.F. Vaccination with recombinant Mycobacterium avium subsp. paratuberculosis proteins induces differential immune responses and protects calves against infection by oral challenge. Vaccine 2008, 26, 1652-1663.

62. Spertini, F.; Audran, R.; Lurati, F.; Ofori-Anyinam, O.; Zysset, F.; Vandepapeliere, P.; Moris, P.; Demoitie, M.A.; Mettens, P.; Vinals, C.; et al. The candidate tuberculosis vaccine Mtb72F/AS02 in PPD positive adults: A randomized controlled phase I/II study. Tuberculosis 2013, 93, 179-188.

63. Lal, H.; Zahaf, T.; Heineman, T.C. Safety and immunogenicity of an AS01-adjuvanted varicella zoster virus subunit candidate vaccine (HZ/su): A phase-I, open-label study in Japanese adults. Hum. Vaccin. Immunother. 2013, 9, 1425-1429.

64. Pichyangkul, S.; Gettayacamin, M.; Miller, R.S.; Lyon, J.A.; Angov, E.; Tongtawe, P.; Ruble, D.L.; Heppner, D.G., Jr.; Kester, K.E.; Ballou, W.R.; et al. Pre-clinical evaluation of the malaria vaccine candidate $P$. falciparum MSP1(42) formulated with novel adjuvants or with alum. Vaccine 2004, 22, 3831-3840.

65. Alonso, P.L.; Sacarlal, J.; Aponte, J.J.; Leach, A.; Macete, E.; Aide, P.; Sigauque, B.; Milman, J.; Mandomando, I.; Bassat, Q.; et al. Duration of protection with RTS,S/AS02A malaria vaccine in prevention of Plasmodium falciparum disease in Mozambican children: single-blind extended follow-up of a randomised controlled trial. Lancet 2005, 366, 2012-2018.

66. Agnandji, S.T.; Lell, B.; Soulanoudjingar, S.S.; Fernandes, J.F.; Abossolo, B.P.; Conzelmann, C.; Methogo, B.G.; Doucka, Y.; Flamen, A.; Mordmuller, B.; et al. First results of phase 3 trial of RTS,S/AS01 malaria vaccine in African children. N. Engl. J. Med. 2011, 365, 1863-1875.

67. Bojang, K.; Milligan, P.; Pinder, M.; Doherty, T.; Leach, A.; Ofori-Anyinam, O.; Lievens, M.; Kester, K.; Schaecher, K.; Ballou, W.R.; et al. Five-year safety and immunogenicity of GlaxoSmithKline's candidate malaria vaccine RTS,S/AS02 following administration to semi-immune adult men living in a malaria-endemic region of The Gambia. Hum. Vaccin. 2009, $5,242-247$.

68. Moore, A.; McCarthy, L.; Mills, K.H. The adjuvant combination monophosphoryl lipid A and QS21 switches $\mathrm{T}$ cell responses induced with a soluble recombinant HIV protein from Th2 to Th1. Vaccine 1999, 17, 2517-2527.

69. Leroux-Roels, I.; Koutsoukos, M.; Clement, F.; Steyaert, S.; Janssens, M.; Bourguignon, P.; Cohen, K.; Altfeld, M.; Vandepapeliere, P.; Pedneault, L.; et al. Strong and persistent CD4 ${ }^{+}$T-cell response in healthy adults immunized with a candidate HIV-1 vaccine containing gp120, Nef and Tat antigens formulated in three adjuvant systems. Vaccine 2010, 28, 7016-7024.

70. Paavonen, J.; Naud, P.; Salmeron, J.; Wheeler, C.M.; Chow, S.N.; Apter, D.; Kitchener, H.; Castellsague, X.; Teixeira, J.C.; Skinner, S.R.; et al. Efficacy of human papillomavirus (HPV)-16/18 AS04-adjuvanted vaccine against cervical infection and precancer caused by oncogenic HPV types (PATRICIA): Final analysis of a double-blind, randomised study in young women. Lancet 2009, 374, 301-314.

71. Bhatla, N.; Suri, V.; Basu, P.; Shastri, S.; Datta, S.K.; Bi, D.; Descamps, D.J.; Bock, H.L. Immunogenicity and safety of human papillomavirus-16/18 AS04-adjuvanted cervical cancer vaccine in healthy Indian women. J. Obstet. Gynaecol. Res. 2010, 36, 123-132. 
72. Romanowski, B.; de Borba, P.C.; Naud, P.S.; Roteli-Martins, C.M.; de Carvalho, N.S.; Teixeira, J.C.; Aoki, F.; Ramjattan, B.; Shier, R.M.; Somani, R.; et al. Sustained efficacy and immunogenicity of the human papillomavirus (HPV)-16/18 AS04-adjuvanted vaccine: Analysis of a randomised placebo-controlled trial up to 6.4 years. Lancet 2009, 374, 1975-1985.

73. Sow, P.S.; Watson-Jones, D.; Kiviat, N.; Changalucha, J.; Mbaye, K.D.; Brown, J.; Bousso, K.; Kavishe, B.; Andreasen, A.; Toure, M.; et al. Safety and immunogenicity of human papillomavirus16/18 AS04-adjuvanted vaccine: A randomized trial in 10-25-year-old HIV-seronegative African girls and young women. J. Infect. Dis. 2013, 207, 1753-1763.

74. Stanberry, L.R.; Spruance, S.L.; Cunningham, A.L.; Bernstein, D.I.; Mindel, A.; Sacks, S.; Tyring, S.; Aoki, F.Y.; Slaoui, M.; Denis, M.; et al. Glycoprotein-D-adjuvant vaccine to prevent genital herpes. N. Engl. J. Med. 2002, 347, 1652-1661.

75. Sokal, E.M.; Hoppenbrouwers, K.; Vandermeulen, C.; Moutschen, M.; Leonard, P.; Moreels, A.; Haumont, M.; Bollen, A.; Smets, F.; Denis, M. Recombinant gp350 vaccine for infectious mononucleosis: A phase 2, randomized, double-blind, placebo-controlled trial to evaluate the safety, immunogenicity, and efficacy of an Epstein-Barr virus vaccine in healthy young adults. J. Infect. Dis. 2007, 196, 1749-1753.

76. Sondak, V.K.; Sosman, J.A. Results of clinical trials with an allogenic melanoma tumor cell lysate vaccine: Melacine. Semin. Cancer Biol. 2003, 13, 409-415.

77. Brichard, V.G.; Lejeune, D. GSK's antigen-specific cancer immunotherapy programme: Pilot results leading to Phase III clinical development. Vaccine 2007, 25, B61-B71.

78. North, S.; Butts, C. Vaccination with BLP25 liposome vaccine to treat non-small cell lung and prostate cancers. Expert Rev. Vaccines 2005, 4, 249-257.

79. Holmberg, L.A.; Sandmaier, B.M. Vaccination with Theratope (STn-KLH) as treatment for breast cancer. Expert Rev. Vaccines 2004, 3, 655-663.

80. Isambert, N.; Fumoleau, P.; Paul, C.; Ferrand, C.; Zanetta, S.; Bauer, J.; Ragot, K.; Lizard, G.; Jeannin, J.F.; Bardou, M. Phase I study of OM-174, a lipid A analogue, with assessment of immunological response, in patients with refractory solid tumors. BMC Cancer 2013, 13, e172.

81. Johnson, D.A.; Sowell, C.G.; Johnson, C.L.; Livesay, M.T.; Keegan, D.S.; Rhodes, M.J.; Ulrich, J.T.; Ward, J.R.; Cantrell, J.L.; Brookshire, V.G. Synthesis and biological evaluation of a new class of vaccine adjuvants: Aminoalkyl glucosaminide 4-phosphates (AGPs). Bioorg. Med. Chem. Lett. 1999, 9, 2273-2278.

82. Treanor, J.J.; Essink, B.; Hull, S.; Reed, S.; Izikson, R.; Patriarca, P.; Goldenthal, K.L.; Kohberger, R.; Dunkle, L.M. Evaluation of safety and immunogenicity of recombinant influenza hemagglutinin (H5/Indonesia/05/2005) formulated with and without a stable oil-in-water emulsion containing glucopyranosyl-lipid A (SE+GLA) adjuvant. Vaccine 2013, 31, 5760-5765.

83. Schulze, H.J.; Cribier, B.; Requena, L.; Reifenberger, J.; Ferrandiz, C.; Garcia, D.A.; Tebbs, V.; McRae, S. Imiquimod 5\% cream for the treatment of superficial basal cell carcinoma: Results from a randomized vehicle-controlled phase III study in Europe. Br. J. Dermatol. 2005, 152, 939-947.

84. Lebwohl, M.; Dinehart, S.; Whiting, D.; Lee, P.K.; Tawfik, N.; Jorizzo, J.; Lee, J.H.; Fox, T.L. Imiquimod 5\% cream for the treatment of actinic keratosis: Results from two phase III, randomized, double-blind, parallel group, vehicle-controlled trials. J. Am. Acad. Dermatol. 2004, 50, 714-721. 
85. Feyerabend, S.; Stevanovic, S.; Gouttefangeas, C.; Wernet, D.; Hennenlotter, J.; Bedke, J.; Dietz, K.; Pascolo, S.; Kuczyk, M.; Rammensee, H.G.; et al. Novel multi-peptide vaccination in Hla-A2 ${ }^{+}$ hormone sensitive patients with biochemical relapse of prostate cancer. Prostate 2009, 69, 917-927.

86. Smorlesi, A.; Papalini, F.; Orlando, F.; Donnini, A.; Re, F.; Provinciali, M. Imiquimod and S-27609 as adjuvants of DNA vaccination in a transgenic murine model of HER2/neu-positive mammary carcinoma. Gene Ther. 2005, 12, 1324-1332.

87. Adams, S.; O’Neill, D.W.; Nonaka, D.; Hardin, E.; Chiriboga, L.; Siu, K.; Cruz, C.M.; Angiulli, A.; Angiulli, F.; Ritter, E.; et al. Immunization of malignant melanoma patients with full-length NY-ESO-1 protein using TLR7 agonist imiquimod as vaccine adjuvant. J. Immunol. 2008, 181, 776-784.

88. Wille-Reece, U.; Flynn, B.J.; Lore, K.; Koup, R.A.; Kedl, R.M.; Mattapallil, J.J.; Weiss, W.R.; Roederer, M.; Seder, R.A. HIV Gag protein conjugated to a Toll-like receptor 7/8 agonist improves the magnitude and quality of Th1 and $\mathrm{CD} 8^{+} \mathrm{T}$ cell responses in nonhuman primates. Proc. Natl. Acad. Sci. USA 2005, 102, 15190-15194.

89. Arevalo, I.; Ward, B.; Miller, R.; Meng, T.C.; Najar, E.; Alvarez, E.; Matlashewski, G.; Llanos-Cuentas, A. Successful treatment of drug-resistant cutaneous leishmaniasis in humans by use of imiquimod, an immunomodulator. Clin. Infect. Dis. 2001, 33, 1847-1851.

90. Tougan, T.; Aoshi, T.; Coban, C.; Katakai, Y.; Kai, C.; Yasutomi, Y.; Ishii, K.J.; Horii, T. TLR9 adjuvants enhance immunogenicity and protective efficacy of the SE36/AHG malaria vaccine in nonhuman primate models. Hum. Vaccin. Immunother. 2013, 9, 283-290;

91. Ellis, R.D.; Martin, L.B.; Shaffer, D.; Long, C.A.; Miura, K.; Fay, M.P.; Narum, D.L.; Zhu, D.; Mullen, G.E.; Mahanty, S.; et al. Phase 1 trial of the Plasmodium falciparum blood stage vaccine MSP1(42)-C1/Alhydrogel with and without CPG 7909 in malaria naive adults. PLoS One 2010, 5 , e8787.

92. Ellis, R.D.; Wu, Y.; Martin, L.B.; Shaffer, D.; Miura, K.; Aebig, J.; Orcutt, A.; Rausch, K.; Zhu, D.; Mogensen, A.; et al. Phase 1 study in malaria naive adults of BSAM2/Alhydrogel(R)+CPG 7909, a blood stage vaccine against P. falciparum malaria. PLoS One 2012, 7, e46094.

93. Cooper, C.L.; Davis, H.L.; Morris, M.L.; Efler, S.M.; Krieg, A.M.; Li, Y.; Laframboise, C.; al Adhami, M.J.; Khaliq, Y.; Seguin, I.; et al. Safety and immunogenicity of CPG 7909 injection as an adjuvant to Fluarix influenza vaccine. Vaccine 2004, 22, 3136-3143.

94. Payette, P.J.; Ma, X.; Weeratna, R.D.; McCluskie, M.J.; Shapiro, M.; Engle, R.E.; Davis, H.L.; Purcell, R.H. Testing of CpG-optimized protein and DNA vaccines against the hepatitis B virus in chimpanzees for immunogenicity and protection from challenge. Intervirology 2006, 49, 144-151.

95. Halperin, S.A.; van Nest, G.; Smith, B.; Abtahi, S.; Whiley, H.; Eiden, J.J. A phase I study of the safety and immunogenicity of recombinant hepatitis B surface antigen co-administered with an immunostimulatory phosphorothioate oligonucleotide adjuvant. Vaccine 2003, 21, 2461-2467.

96. Halperin, S.A.; McNeil, S.; Langley, J.M.; Smith, B.; MacKinnon-Cameron, D.; McCall-Sani, R.; Heyward, W.L.; Martin, J.T. Safety and immunogenicity of different two-dose regimens of an investigational hepatitis B vaccine (hepatitis B surface antigen co-administered with an immunostimulatory phosphorothioate oligodeoxyribonucleotide) in healthy young adults. Vaccine 2012, 30, 5445-5448.

97. Sablan, B.P.; Kim, D.J.; Barzaga, N.G.; Chow, W.C.; Cho, M.; Ahn, S.H.; Hwang, S.G.; Lee, J.H.; Namini, H.; Heyward, W.L. Demonstration of safety and enhanced seroprotection against 
hepatitis B with investigational HBsAg-1018 ISS vaccine compared to a licensed hepatitis B vaccine. Vaccine 2012, 30, 2689-2696.

98. Hopkins, R.J.; Daczkowski, N.F.; Kaptur, P.E.; Muse, D.; Sheldon, E.; LaForce, C.; Sari, S.; Rudge, T.L.; Bernton, E. Randomized, double-blind, placebo-controlled, safety and immunogenicity study of 4 formulations of Anthrax Vaccine Adsorbed plus CPG 7909 (AV7909) in healthy adult volunteers. Vaccine 2013, 31, 3051-3058.

99. Wang, H.L.; Xu, H.; Lu, W.H.; Zhu, L.; Yu, Y.H.; Hong, F.Z. In vitro and in vivo evaluations of human papillomavirus type 16 (HPV16)-derived peptide-loaded dendritic cells (DCs) with a CpG oligodeoxynucleotide (CpG-ODN) adjuvant as tumor vaccines for immunotherapy of cervical cancer. Arch. Gynecol. Obstet. 2014, 289, 155-162.

100. Millward, M.; Underhill, C.; Lobb, S.; McBurnie, J.; Meech, S.J.; Gomez-Navarro, J.; Marshall, M.A.; Huang, B.; Mather, C.B. Phase I study of tremelimumab (CP-675 206) plus PF-3512676 (CPG 7909) in patients with melanoma or advanced solid tumours. Br. J. Cancer 2013, 108, 1998-2004.

101. Karbach, J.; Neumann, A.; Atmaca, A.; Wahle, C.; Brand, K.; von Boehmer, L.; Knuth, A.; Bender, A.; Ritter, G.; Old, L.J.; et al. Efficient in vivo priming by vaccination with recombinant NY-ESO-1 protein and CpG in antigen naive prostate cancer patients. Clin. Cancer Res. 2011, $17,861-870$.

102. Hofmann, M.A.; Kors, C.; Audring, H.; Walden, P.; Sterry, W.; Trefzer, U. Phase 1 evaluation of intralesionally injected TLR9-agonist PF-3512676 in patients with basal cell carcinoma or metastatic melanoma. J. Immunother. 2008, 31, 520-527.

103. Manegold, C.; Gravenor, D.; Woytowitz, D.; Mezger, J.; Hirsh, V.; Albert, G.; Al-Adhami, M.; Readett, D.; Krieg, A.M.; Leichman, C.G. Randomized phase II trial of a toll-like receptor 9 agonist oligodeoxynucleotide, PF-3512676, in combination with first-line taxane plus platinum chemotherapy for advanced-stage non-small-cell lung cancer. J. Clin. Oncol. 2008, 26, 3979-3986.

104. Speiser, D.E.; Schwarz, K.; Baumgaertner, P.; Manolova, V.; Devevre, E.; Sterry, W.; Walden, P.; Zippelius, A.; Conzett, K.B.; Senti, G.; et al. Memory and effector CD8 T-cell responses after nanoparticle vaccination of melanoma patients. J. Immunother. 2010, 33, 848-858.

105. Kruit, W.H.; Suciu, S.; Dreno, B.; Mortier, L.; Robert, C.; Chiarion-Sileni, V.; Maio, M.; Testori, A.; Dorval, T.; Grob, J.J.; et al. Selection of immunostimulant AS15 for active immunization with MAGE-A3 protein: results of a randomized phase II study of the European Organisation for Research and Treatment of Cancer Melanoma Group in Metastatic Melanoma. J. Clin. Oncol. 2013, 31, 2413-2420.

106. Cataldi, A.; Yevsa, T.; Vilte, D.A.; Schulze, K.; Castro-Parodi, M.; Larzabal, M.; Ibarra, C.; Mercado, E.C.; Guzman, C.A. Efficient immune responses against Intimin and EspB of enterohaemorragic Escherichia coli after intranasal vaccination using the TLR2/6 agonist MALP-2 as adjuvant. Vaccine 2008, 26, 5662-5667.

107. Behrens, R.H.; Cramer, J.P.; Jelinek, T.; Shaw, H.; von, S.F.; Wilbraham, D.; Weinke, T.; Bell, D.J.; Asturias, E.; Pauwells, H.L.; et al. Efficacy and safety of a patch vaccine containing heat-labile toxin from Escherichia coli against travellers' diarrhoea: A phase 3, randomised, double-blind, placebo-controlled field trial in travellers from Europe to Mexico and Guatemala. Lancet Infect. Dis. 2013, 14, 197-204. 
108. Steere, A.C.; Sikand, V.K.; Meurice, F.; Parenti, D.L.; Fikrig, E.; Schoen, R.T.; Nowakowski, J.; Schmid, C.H.; Laukamp, S.; Buscarino, C.; et al. Vaccination against Lyme disease with recombinant Borrelia burgdorferi outer-surface lipoprotein A with adjuvant. Lyme Disease Vaccine Study Group. N. Engl. J. Med. 1998, 339, 209-215.

109. Nigrovic, L.E.; Thompson, K.M. The Lyme vaccine: A cautionary tale. Epidemiol. Infect. 2007, $135,1-8$.

110. Nardin, E.H.; Calvo-Calle, J.M.; Oliveira, G.A.; Nussenzweig, R.S.; Schneider, M.; Tiercy, J.M.; Loutan, L.; Hochstrasser, D.; Rose, K. A totally synthetic polyoxime malaria vaccine containing Plasmodium falciparum $\mathrm{B}$ cell and universal $\mathrm{T}$ cell epitopes elicits immune responses in volunteers of diverse HLA types. J. Immunol. 2001, 166, 481-489.

111. Lowell, G.H.; Ballou, W.R.; Smith, L.F.; Wirtz, R.A.; Zollinger, W.D.; Hockmeyer, W.T. Proteosome-lipopeptide vaccines: Enhancement of immunogenicity for malaria CS peptides. Science 1988, 240, 800-802.

112. Vitiello, A.; Ishioka, G.; Grey, H.M.; Rose, R.; Farness, P.; LaFond, R.; Yuan, L.; Chisari, F.V.; Furze, J.; Bartholomeuz, R. Development of a lipopeptide-based therapeutic vaccine to treat chronic HBV infection. I. Induction of a primary cytotoxic T lymphocyte response in humans. J. Clin. Invest. 1995, 95, 341-349.

113. Livingston, B.D.; Crimi, C.; Fikes, J.; Chesnut, R.W.; Sidney, J.; Sette, A. Immunization with the HBV core 18-27 epitope elicits CTL responses in humans expressing different HLA-A2 supertype molecules. Hum. Immunol. 1999, 60, 1013-1017.

114. Durier, C.; Launay, O.; Meiffredy, V.; Saidi, Y.; Salmon, D.; Levy, Y.; Guillet, J.G.; Pialoux, G.; Aboulker, J.P. Clinical safety of HIV lipopeptides used as vaccines in healthy volunteers and HIV-infected adults. AIDS 2006, 20, 1039-1049.

115. Neidleman, J.A.; Vajdy, M.; Ugozzoli, M.; Ott, G.; O’Hagan, D. Genetically detoxified mutants of heat-labile enterotoxin from Escherichia coli are effective adjuvants for induction of cytotoxic T-cell responses against HIV-1 gag-p55. Immunology 2000, 101, 154-160.

116. Massari, P.; Toussi, D.N.; Tifrea, D.F.; de la Maza, L.M. Toll-Like receptor 2-dependent activity of native major outer membrane protein proteosomes of Chlamydia trachomatis. Infect. Immun. 2013, 81, 303-310.

117. Moreno-Eutimio, M.A.; Tenorio-Calvo, A.; Pastelin-Palacios, R.; Perez-Shibayama, C.; Gil-Cruz, C.; Lopez-Santiago, R.; Baeza, I.; Fernandez-Mora, M.; Bonifaz, L.; Isibasi, A.; et al. Salmonella Typhi OmpS1 and OmpS2 porins are potent protective immunogens with adjuvant properties. Immunology 2013, 139, 459-471.

118. Snapper, C.M.; Rosas, F.R.; Kehry, M.R.; Mond, J.J.; Wetzler, L.M. Neisserial porins may provide critical second signals to polysaccharide-activated murine B cells for induction of immunoglobulin secretion. Infect. Immun. 1997, 65, 3203-3208.

119. Mackinnon, F.G.; Ho, Y.; Blake, M.S.; Michon, F.; Chandraker, A.; Sayegh, M.H.; Wetzler, L.M. The role of $\mathrm{B} / \mathrm{T}$ costimulatory signals in the immunopotentiating activity of neisserial porin. J. Infect. Dis. 1999, 180, 755-761.

120. Donnelly, J.J.; Deck, R.R.; Liu, M.A. Immunogenicity of a Haemophilus influenzae polysaccharide-Neisseria meningitidis outer membrane protein vaccine. J. Immunol. 1990, 145, 3071-3079. 
121. Fusco, P.C.; Michon, F.; Laude-Sharp, M.; Minetti, C.A.; Huang, C.H.; Heron, I.; Blake, M.S. Preclinical studies on a recombinant group B meningococcal porin as a carrier for a novel Haemophilus influenzae type B conjugate vaccine. Vaccine 1998, 16, 1842-1849.

122. Burke, J.M.; Ganley-Leal, L.M.; Khatri, A.; Wetzler, L.M. Neisseria meningitidis PorB, a TLR2 ligand, induces an antigen-specific eosinophil recall response: Potential adjuvant for helminth vaccines? J. Immunol. 2007, 179, 3222-3230.

123. Chiavolini, D.; Weir, S.; Murphy, J.R.; Wetzler, L.M. Neisseria meningitidis PorB, a Toll-like receptor 2 ligand, improves the capacity of Francisella tularensis lipopolysaccharide to protect mice against experimental tularemia. Clin. Vaccine Immunol. 2008, 15, 1322-1329.

124. Mizel, S.B.; Graff, A.H.; Sriranganathan, N.; Ervin, S.; Lees, C.J.; Lively, M.O.; Hantgan, R.R.; Thomas, M.J.; Wood, J.; Bell, B. Flagellin-F1-V fusion protein is an effective plague vaccine in mice and two species of nonhuman primates. Clin. Vaccine Immunol. 2009, 16, 21-28.

125. McDonald, W.F.; Huleatt, J.W.; Foellmer, H.G.; Hewitt, D.; Tang, J.; Desai, P.; Price, A.; Jacobs, A.; Takahashi, V.N.; Huang, Y.; et al. A West Nile virus recombinant protein vaccine that coactivates innate and adaptive immunity. J. Infect. Dis. 2007, 195, 1607-1617.

126. Hedayat, M.; Takeda, K.; Rezaei, N. Prophylactic and therapeutic implications of toll-like receptor ligands. Med. Res. Rev. 2012, 32, 294-325.

127. Huleatt, J.W.; Jacobs, A.R.; Tang, J.; Desai, P.; Kopp, E.B.; Huang, Y.; Song, L.; Nakaar, V.; Powell, T.J. Vaccination with recombinant fusion proteins incorporating Toll-like receptor ligands induces rapid cellular and humoral immunity. Vaccine 2007, 25, 763-775.

128. Carapau, D.; Mitchell, R.; Nacer, A.; Shaw, A.; Othoro, C.; Frevert, U.; Nardin, E. Protective humoral immunity elicited by a needle-free malaria vaccine comprised of a chimeric Plasmodium falciparum circumsporozoite protein and a Toll-like receptor 5 agonist, flagellin. Infect. Immun. 2013, 81, 4350-4362.

129. Sun, Y.; Shi, W.; Yang, J.Y.; Zhou, D.H.; Chen, Y.Q.; Zhang, Y.; Yang, Y.; He, B.X.; Zhong, M.H.; Li, Y.M.; et al. Flagellin-PAc fusion protein is a high-efficacy anti-caries mucosal vaccine. J. Dent. Res. 2012, 91, 941-947.

130. Jones, R.M.; Sloane, V.M.; Wu, H.; Luo, L.; Kumar, A.; Kumar, M.V.; Gewirtz, A.T.; Neish, A.S. Flagellin administration protects gut mucosal tissue from irradiation-induced apoptosis via MKP-7 activity. Gut 2011, 60, 648-657.

131. Nguyen, C.T.; Hong, S.H.; Sin, J.I.; Vu, H.V.; Jeong, K.; Cho, K.O.; Uematsu, S.; Akira, S.; Lee, S.E.; Rhee, J.H. Flagellin enhances tumor-specific $\mathrm{CD}^{+} \mathrm{T}$ cell immune responses through TLR5 stimulation in a therapeutic cancer vaccine model. Vaccine 2013, 31, 3879-3887.

132. Skountzou, I.; Martin, M.P.; Wang, B.; Ye, L.; Koutsonanos, D.; Weldon, W.; Jacob, J.; Compans, R.W. Salmonella flagellins are potent adjuvants for intranasally administered whole inactivated influenza vaccine. Vaccine 2010, 28, 4103-4112.

133. Hong, S.H.; Byun, Y.H.; Nguyen, C.T.; Kim, S.Y.; Seong, B.L.; Park, S.; Woo, G.J.; Yoon, Y.; Koh, J.T.; Fujihashi, K.; et al. Intranasal administration of a flagellin-adjuvanted inactivated influenza vaccine enhances mucosal immune responses to protect mice against lethal infection. Vaccine 2012, 30, 466-474.

134. Taylor, D.N.; Treanor, J.J.; Sheldon, E.A.; Johnson, C.; Umlauf, S.; Song, L.; Kavita, U.; Liu, G.; Tussey, L.; Ozer, K.; et al. Development of VAX128, a recombinant hemagglutinin (HA) 
influenza-flagellin fusion vaccine with improved safety and immune response. Vaccine 2012, 30, 5761-5769.

135. Treanor, J.J.; Taylor, D.N.; Tussey, L.; Hay, C.; Nolan, C.; Fitzgerald, T.; Liu, G.; Kavita, U.; Song, L.; Dark, I.; et al. Safety and immunogenicity of a recombinant hemagglutinin influenza-flagellin fusion vaccine (VAX125) in healthy young adults. Vaccine 2010, 28, 8268-8274.

136. Liu, G.; Tarbet, B.; Song, L.; Reiserova, L.; Weaver, B.; Chen, Y.; Li, H.; Hou, F.; Liu, X.; Parent, J.; et al. Immunogenicity and efficacy of flagellin-fused vaccine candidates targeting 2009 pandemic H1N1 influenza in mice. PLoS. One 2011, 6, e20928.

137. Talbot, H.K.; Rock, M.T.; Johnson, C.; Tussey, L.; Kavita, U.; Shanker, A.; Shaw, A.R.; Taylor, D.N. Immunopotentiation of trivalent influenza vaccine when given with VAX102, a recombinant influenza M2e vaccine fused to the TLR5 ligand flagellin. PLoS One 2010, 5, e14442.

138. Turley, C.B.; Rupp, R.E.; Johnson, C.; Taylor, D.N.; Wolfson, J.; Tussey, L.; Kavita, U.; Stanberry, L.; Shaw, A. Safety and immunogenicity of a recombinant M2e-flagellin influenza vaccine (STF2.4xM2e) in healthy adults. Vaccine 2011, 29, 5145-5152.

139. Jasani, B.; Navabi, H.; Adams, M. Ampligen: A potential toll-like 3 receptor adjuvant for immunotherapy of cancer. Vaccine 2009, 27, 3401-3404.

140. Christensen, D.; Foged, C.; Rosenkrands, I.; Lundberg, C.V.; Andersen, P.; Agger, E.M.; Nielsen, H.M. CAF01 liposomes as a mucosal vaccine adjuvant: In vitro and in vivo investigations. Int. J. Pharm. 2010, 390, 19-24.

141. Nordly, P.; Rose, F.; Christensen, D.; Nielsen, H.M.; Andersen, P.; Agger, E.M.; Foged, C. Immunity by formulation design: induction of high $\mathrm{CD}^{+} \mathrm{T}$-cell responses by poly(I:C) incorporated into the CAF01 adjuvant via a double emulsion method. J. Control. Release 2011, 150, 307-317.

142. Dasari, P.; Nicholson, I.C.; Hodge, G.; Dandie, G.W.; Zola, H. Expression of toll-like receptors on B lymphocytes. Cell Immunol. 2005, 236, 140-145.

143. Chow, J.C.; Young, D.W.; Golenbock, D.T.; Christ, W.J.; Gusovsky, F. Toll-like receptor-4 mediates lipopolysaccharide-induced signal transduction. J. Biol. Chem. 1999, 274, 10689-10692.

144. Tada, H.; Nemoto, E.; Shimauchi, H.; Watanabe, T.; Mikami, T.; Matsumoto, T.; Ohno, N.; Tamura, H.; Shibata, K.; Akashi, S.; et al. Saccharomyces cerevisiae- and Candida albicans-derived mannan induced production of tumor necrosis factor alpha by human monocytes in a CD14- and Toll-like receptor 4-dependent manner. Microbiol. Immunol. 2002, 46, 503-512.

145. Kurt-Jones, E.A.; Popova, L.; Kwinn, L.; Haynes, L.M.; Jones, L.P.; Tripp, R.A.; Walsh, E.E.; Freeman, M.W.; Golenbock, D.T.; Anderson, L.J.; et al. Pattern recognition receptors TLR4 and CD14 mediate response to respiratory syncytial virus. Nat. Immunol. 2000, 1, 398-401.

146. Biragyn, A.; Ruffini, P.A.; Leifer, C.A.; Klyushnenkova, E.; Shakhov, A.; Chertov, O.; Shirakawa, A.K.; Farber, J.M.; Segal, D.M.; Oppenheim, J.J.; et al. Toll-like receptor 4-dependent activation of dendritic cells by beta-defensin 2. Science 2002, 298, 1025-1029.

147. Peri, F.; Calabrese, V. Toll-like Receptor 4 (TLR4) modulation by synthetic and natural compounds: An update. J. Med. Chem. 2013, doi:10.1021/jm401006s.

148. Kim, H.M.; Park, B.S.; Kim, J.I.; Kim, S.E.; Lee, J.; Oh, S.C.; Enkhbayar, P.; Matsushima, N.; Lee, H.; Yoo, O.J.; et al. Crystal structure of the TLR4-MD-2 complex with bound endotoxin antagonist Eritoran. Cell 2007, 130, 906-917. 
149. Schumann, R.R.; Leong, S.R.; Flaggs, G.W.; Gray, P.W.; Wright, S.D.; Mathison, J.C.; Tobias, P.S.; Ulevitch, R.J. Structure and function of lipopolysaccharide binding protein. Science 1990, 249, 1429-1431.

150. Latz, E.; Visintin, A.; Lien, E.; Fitzgerald, K.A.; Monks, B.G.; Kurt-Jones, E.A.; Golenbock, D.T.; Espevik, T. Lipopolysaccharide rapidly traffics to and from the Golgi apparatus with the toll-like receptor 4-MD-2-CD14 complex in a process that is distinct from the initiation of signal transduction. J. Biol. Chem. 2002, 277, 47834-47843.

151. Thompson, B.S.; Chilton, P.M.; Ward, J.R.; Evans, J.T.; Mitchell, T.C. The low-toxicity versions of LPS, MPL adjuvant and RC529, are efficient adjuvants for $\mathrm{CD}^{+} \mathrm{T}$ cells. J. Leukoc. Biol. 2005, 78, 1273-1280.

152. Mata-Haro, V.; Cekic, C.; Martin, M.; Chilton, P.M.; Casella, C.R.; Mitchell, T.C. The vaccine adjuvant monophosphoryl lipid A as a TRIF-biased agonist of TLR4. Science 2007, 316, 1628-1632.

153. Garcon, N.; Chomez, P.; van Mechelen, M. GlaxoSmithKline adjuvant systems in vaccines: Concepts, achievements and perspectives. Expert Rev. Vaccines 2007, 6, 723-739.

154. Didierlaurent, A.M.; Morel, S.; Lockman, L.; Giannini, S.L.; Bisteau, M.; Carlsen, H.; Kielland, A.; Vosters, O.; Vanderheyde, N.; Schiavetti, F.; et al. AS04, an aluminum salt- and TLR4 agonist-based adjuvant system, induces a transient localized innate immune response leading to enhanced adaptive immunity. J. Immunol. 2009, 183, 6186-6197.

155. Morefield, G.L.; Hawkins, L.D.; Ishizaka, S.T.; Kissner, T.L.; Ulrich, R.G. Synthetic Toll-like receptor 4 agonist enhances vaccine efficacy in an experimental model of toxic shock syndrome. Clin. Vaccine Immunol. 2007, 14, 1499-1504.

156. Gorden, K.B.; Gorski, K.S.; Gibson, S.J.; Kedl, R.M.; Kieper, W.C.; Qiu, X.; Tomai, M.A.; Alkan, S.S.; Vasilakos, J.P. Synthetic TLR agonists reveal functional differences between human TLR7 and TLR8. J. Immunol. 2005, 174, 1259-1268.

157. Ito, T.; Amakawa, R.; Kaisho, T.; Hemmi, H.; Tajima, K.; Uehira, K.; Ozaki, Y.; Tomizawa, H.; Akira, S.; Fukuhara, S. Interferon-alpha and interleukin-12 are induced differentially by Toll-like receptor 7 ligands in human blood dendritic cell subsets. J. Exp. Med. 2002, 195, 1507-1512.

158. Bishop, G.A.; Hsing, Y.; Hostager, B.S.; Jalukar, S.V.; Ramirez, L.M.; Tomai, M.A. Molecular mechanisms of B lymphocyte activation by the immune response modifier R-848. J. Immunol. 2000, 165, 5552-5557.

159. Hart, O.M.; Athie-Morales, V.; O’Connor, G.M.; Gardiner, C.M. TLR7/8-mediated activation of human NK cells results in accessory cell-dependent IFN-gamma production. J. Immunol. 2005, 175, 1636-1642.

160. Peng, G.; Guo, Z.; Kiniwa, Y.; Voo, K.S.; Peng, W.; Fu, T.; Wang, D.Y.; Li, Y.; Wang, H.Y.; Wang, R.F. Toll-like receptor 8 -mediated reversal of $\mathrm{CD}^{+}$regulatory $\mathrm{T}$ cell function. Science 2005, 309, 1380-1384.

161. Heil, F.; Hemmi, H.; Hochrein, H.; Ampenberger, F.; Kirschning, C.; Akira, S.; Lipford, G.; Wagner, H.; Bauer, S. Species-specific recognition of single-stranded RNA via toll-like receptor 7 and 8. Science 2004, 303, 1526-1529.

162. Jurk, M.; Heil, F.; Vollmer, J.; Schetter, C.; Krieg, A.M.; Wagner, H.; Lipford, G.; Bauer, S. Human TLR7 or TLR8 independently confer responsiveness to the antiviral compound R-848. Nat. Immunol. 2002, 3, doi:10.1038/ni0602-499. 
163. Hornung, V.; Rothenfusser, S.; Britsch, S.; Krug, A.; Jahrsdorfer, B.; Giese, T.; Endres, S.; Hartmann, G. Quantitative expression of toll-like receptor 1-10 mRNA in cellular subsets of human peripheral blood mononuclear cells and sensitivity to $\mathrm{CpG}$ oligodeoxynucleotides. J. Immunol. 2002, $168,4531-4537$.

164. Klinman, D.M.; Yi, A.K.; Beaucage, S.L.; Conover, J.; Krieg, A.M. CpG motifs present in bacteria DNA rapidly induce lymphocytes to secrete interleukin 6, interleukin 12, and interferon gamma. Proc. Natl. Acad. Sci. USA 1996, 93, 2879-2883.

165. Overstreet, M.G.; Freyberger, H.; Cockburn, I.A.; Chen, Y.C.; Tse, S.W.; Zavala, F. CpG-enhanced $\mathrm{CD}^{+} \mathrm{T}$-cell responses to peptide immunization are severely inhibited by B cells. Eur. J. Immunol. 2010, 40, 124-133.

166. Krug, A.; Towarowski, A.; Britsch, S.; Rothenfusser, S.; Hornung, V.; Bals, R.; Giese, T.; Engelmann, H.; Endres, S.; Krieg, A.M.; et al.Toll-like receptor expression reveals CpG DNA as a unique microbial stimulus for plasmacytoid dendritic cells which synergizes with CD40 ligand to induce high amounts of IL-12. Eur. J. Immunol. 2001, 31, 3026-3037.

167. Roman, M.; Martin-Orozco, E.; Goodman, J.S.; Nguyen, M.D.; Sato, Y.; Ronaghy, A.; Kornbluth, R.S.; Richman, D.D.; Carson, D.A.; Raz, E. Immunostimulatory DNA sequences function as T helper-1-promoting adjuvants. Nat. Med. 1997, 3, 849-854.

168. Bauer, S.; Kirschning, C.J.; Hacker, H.; Redecke, V.; Hausmann, S.; Akira, S.; Wagner, H.; Lipford, G.B. Human TLR9 confers responsiveness to bacterial DNA via species-specific CpG motif recognition. Proc. Natl. Acad. Sci. USA 2001, 98, 9237-9242.

169. Verthelyi, D.; Ishii, K.J.; Gursel, M.; Takeshita, F.; Klinman, D.M. Human peripheral blood cells differentially recognize and respond to two distinct CPG motifs. J. Immunol. 2001, 166, 2372-2377.

170. Jurk, M.; Schulte, B.; Kritzler, A.; Noll, B.; Uhlmann, E.; Wader, T.; Schetter, C.; Krieg, A.M.; Vollmer, J. C-Class CpG ODN: Sequence requirements and characterization of immunostimulatory activities on mRNA level. Immunobiology 2004, 209, 141-154.

171. Verthelyi, D.; Klinman, D.M. Immunoregulatory activity of $\mathrm{CpG}$ oligonucleotides in humans and nonhuman primates. Clin. Immunol. 2003, 109, 64-71.

172. Shirota, H.; Klinman, D.M. Recent progress concerning CpG DNA and its use as a vaccine adjuvant. Expert Rev. Vaccines 2014, 13, 299-312.

173. Takeuchi, O.; Kawai, T.; Muhlradt, P.F.; Morr, M.; Radolf, J.D.; Zychlinsky, A.; Takeda, K.; Akira, S. Discrimination of bacterial lipoproteins by Toll-like receptor 6. Int. Immunol. 2001, 13, 933-940.

174. Takeuchi, O.; Sato, S.; Horiuchi, T.; Hoshino, K.; Takeda, K.; Dong, Z.; Modlin, R.L.; Akira, S. Cutting edge: Role of Toll-like receptor 1 in mediating immune response to microbial lipoproteins. J. Immunol. 2002, 169, 10-14.

175. Hoebe, K.; Georgel, P.; Rutschmann, S.; Du, X.; Mudd, S.; Crozat, K.; Sovath, S.; Shamel, L.; Hartung, T.; Zahringer, U.; et al. CD36 is a sensor of diacylglycerides. Nature 2005, 433, 523-527.

176. Ranoa, D.R.; Kelley, S.L.; Tapping, R.I. Human lipopolysaccharide-binding protein (LBP) and CD14 independently deliver triacylated lipoproteins to Toll-like receptor 1 (TLR1) and TLR2 and enhance formation of the ternary signaling complex. J. Biol. Chem. 2013, 288, 9729-9741. 
177. Buwitt-Beckmann, U.; Heine, H.; Wiesmuller, K.H.; Jung, G.; Brock, R.; Akira, S.; Ulmer, A.J. Toll-like receptor 6-independent signaling by diacylated lipopeptides. Eur. J. Immunol. 2005, 35, 282-289.

178. Iwaki, D.; Mitsuzawa, H.; Murakami, S.; Sano, H.; Konishi, M.; Akino, T.; Kuroki, Y. The extracellular toll-like receptor 2 domain directly binds peptidoglycan derived from Staphylococcus aureus. J. Biol. Chem. 2002, 277, 24315-24320.

179. Tapping, R.I.; Tobias, P.S. Mycobacterial lipoarabinomannan mediates physical interactions between TLR1 and TLR2 to induce signaling. J. Endotoxin. Res. 2003, 9, 264-268.

180. Yadav, M.; Schorey, J.S. The beta-glucan receptor dectin-1 functions together with TLR2 to mediate macrophage activation by mycobacteria. Blood 2006, 108, 3168-3175.

181. Sato, M.; Sano, H.; Iwaki, D.; Kudo, K.; Konishi, M.; Takahashi, H.; Takahashi, T.; Imaizumi, H.; Asai, Y.; Kuroki, Y. Direct binding of Toll-like receptor 2 to zymosan, and zymosan-induced NF-kappa B activation and TNF-alpha secretion are down-regulated by lung collectin surfactant protein A. J. Immunol. 2003, 171, 417-425.

182. Barbalat, R.; Lau, L.; Locksley, R.M.; Barton, G.M. Toll-like receptor 2 on inflammatory monocytes induces type I interferon in response to viral but not bacterial ligands. Nat. Immunol. 2009, 10, 1200-1207.

183. Kirschning, C.J.; Schumann, R.R. TLR2: Cellular sensor for microbial and endogenous molecular patterns. Curr. Top. Microbiol Immunol. 2002, 270, 121-144.

184. Hajishengallis, G.; Tapping, R.I.; Harokopakis, E.; Nishiyama, S.; Ratti, P.; Schifferle, R.E.; Lyle, E.A.; Triantafilou, M.; Triantafilou, K.; Yoshimura, F. Differential interactions of fimbriae and lipopolysaccharide from Porphyromonas gingivalis with the Toll-like receptor 2-centred pattern recognition apparatus. Cell Microbiol. 2006, 8, 1557-1570.

185. Nair, S.; Ramaswamy, P.A.; Ghosh, S.; Joshi, D.C.; Pathak, N.; Siddiqui, I.; Sharma, P.; Hasnain, S.E.; Mande, S.C.; Mukhopadhyay, S. The PPE18 of Mycobacterium tuberculosis interacts with TLR2 and activates IL-10 induction in macrophage. J. Immunol. 2009, 183, 6269-6281.

186. Jin, M.S.; Kim, S.E.; Heo, J.Y.; Lee, M.E.; Kim, H.M.; Paik, S.G.; Lee, H.; Lee, J.O. Crystal structure of the TLR1-TLR2 heterodimer induced by binding of a tri-acylated lipopeptide. Cell 2007, 130, 1071-1082.

187. Liang, S.; Hosur, K.B.; Lu, S.; Nawar, H.F.; Weber, B.R.; Tapping, R.I.; Connell, T.D.; Hajishengallis, G. Mapping of a microbial protein domain involved in binding and activation of the TLR2/TLR1 heterodimer. J. Immunol. 2009, 182, 2978-2985.

188. Kattner, C.; Toussi, D.N.; Zaucha, J.; Wetzler, L.M.; Ruppel, N.; Zachariae, U.; Massari, P.; Tanabe, M. Crystallographic analysis of Neisseria meningitidis PorB extracellular loops potentially implicated in TLR2 recognition. J. Struct. Biol. 2013, 185, 440-447.

189. Chua, B.Y.; Olson, M.R.; Bedoui, S.; Sekiya, T.; Wong, C.Y.; Turner, S.J.; Jackson, D.C. The use of a TLR2 agonist-based adjuvant for enhancing effector and memory CD8 T-cell responses. Immunol. Cell Biol. 2014, doi:10.1038/icb.2013.102.

190. DePaolo, R.W.; Kamdar, K.; Khakpour, S.; Sugiura, Y.; Wang, W.; Jabri, B. A specific role for TLR1 in protective T(H)17 immunity during mucosal infection. J. Exp. Med. 2012, 209, 1437-1444.

191. Prajeeth, C.K.; Jirmo, A.C.; Krishnaswamy, J.K.; Ebensen, T.; Guzman, C.A.; Weiss, S.; Constabel, H.; Schmidt, R.E.; Behrens, G.M. The synthetic TLR2 agonist BPPcysMPEG leads to 
efficient cross-priming against co-administered and linked antigens. Eur. J. Immunol. 2010, 40, $1272-1283$.

192. Deprez, B.; Sauzet, J.P.; Boutillon, C.; Martinon, F.; Tartar, A.; Sergheraert, C.; Guillet, J.G.; Gomard, E.; Gras-Masse, H. Comparative efficiency of simple lipopeptide constructs for in vivo induction of virus-specific CTL. Vaccine 1996, 14, 375-382.

193. Nikaido, H. Molecular basis of bacterial outer membrane permeability revisited. Microbiol. Mol. Biol. Rev. 2003, 67, 593-656.

194. Massari, P.; Visintin, A.; Gunawardana, J.; Halmen, K.A.; King, C.A.; Golenbock, D.T.; Wetzler, L.M. Meningococcal porin PorB binds to TLR2 and requires TLR1 for signaling. J. Immunol. 2006, 176, 2373-2380.

195. Liu, X.; Wetzler, L.M.; Massari, P. The PorB porin from commensal Neisseria lactamica induces Th1 and Th2 immune responses to ovalbumin in mice and is a potential immune adjuvant. Vaccine 2008, 26, 786-796.

196. Toussi, D.N.; Liu, X.; Massari, P. The fomA porin from Fusobacterium nucleatum is a toll-like receptor 2 agonist with immune adjuvant activity. Clin. Vaccine Immunol. 2012, 19, 1093-1101.

197. Ray, A.; Chatterjee, N.S.; Bhattacharya, S.K.; Biswas, T. Porin of Shigella dysenteriae enhances mRNA levels for Toll-like receptor 2 and MyD88, up-regulates CD80 of murine macrophage, and induces the release of interleukin-12. FEMS Immunol. Med. Microbiol. 2003, 39, 213-219.

198. Banerjee, P.; Biswas, A.; Biswas, T. Porin-incorporated liposome induces Toll-like receptors 2- and 6-dependent maturation and type 1 response of dendritic cell. Int. Immunol. 2008, 20, 1551-1563.

199. Wetzler, L.M.; Ho, Y.; Reiser, H. Neisserial porins induce B lymphocytes to express costimulatory B7-2 molecules and to proliferate. J. Exp. Med. 1996, 183, 1151-1159.

200. Platt, A.; Macleod, H.; Massari, P.; Liu, X.; Wetzler, L. In vivo and In vitro characterization of the immune stimulating activity of the Neisserial Porin PorB. PLoS One 2013, 8, e82171.

201. Livingston, P.O.; Calves, M.J.; Helling, F.; Zollinger, W.D.; Blake, M.S.; Lowell, G.H. GD3/proteosome vaccines induce consistent IgM antibodies against the ganglioside GD3. Vaccine 1993, 11, 1199-1204.

202. Spangler, B.D. Structure and function of cholera toxin and the related Escherichia coli heat-labile enterotoxin. Microbiol. Rev. 1992, 56, 622-647.

203. Van den Akker, F.; Sarfaty, S.; Twiddy, E.M.; Connell, T.D.; Holmes, R.K.; Hol, W.G. Crystal structure of a new heat-labile enterotoxin, LT-IIb. Structure 1996, 4, 665-678.

204. Nawar, H.F.; Greene, C.J.; Lee, C.H.; Mandell, L.M.; Hajishengallis, G.; Connell, T.D. LT-IIc, a new member of the type II heat-labile enterotoxin family, exhibits potent immunomodulatory properties that are different from those induced by LT-IIa or LT-IIb. Vaccine 2011, 29, 721-727.

205. Fujihashi, K.; Koga, T.; McGhee, J.R. Mucosal vaccination and immune responses in the elderly. Vaccine 2000, 18, 1675-1680.

206. Norton, E.B.; Lawson, L.B.; Freytag, L.C.; Clements, J.D. Characterization of a mutant Escherichia coli heat-labile toxin, LT(R192G/L211A), as a safe and effective oral adjuvant. Clin. Vaccine Immunol. 2011, 18, 546-551.

207. Marchetti, M.; Rossi, M.; Giannelli, V.; Giuliani, M.M.; Pizza, M.; Censini, S.; Covacci, A.; Massari, P.; Pagliaccia, C.; Manetti, R.; et al. Protection against Helicobacter pylori infection in 
mice by intragastric vaccination with $H$. pylori antigens is achieved using a non-toxic mutant of E. coli heat-labile enterotoxin (LT) as adjuvant. Vaccine 1998, 16, 33-37.

208. Lewis, D.J.; Huo, Z.; Barnett, S.; Kromann, I.; Giemza, R.; Galiza, E.; Woodrow, M.; Thierry-Carstensen, B.; Andersen, P.; Novicki, D.; et al. Transient facial nerve paralysis (Bell's palsy) following intranasal delivery of a genetically detoxified mutant of Escherichia coli heat labile toxin. PLoS One 2009, 4 e6999.

209. Liang, S.; Wang, M.; Triantafilou, K.; Triantafilou, M.; Nawar, H.F.; Russell, M.W.; Connell, T.D.; Hajishengallis, G. The A subunit of type IIb enterotoxin (LT-IIb) suppresses the proinflammatory potential of the B subunit and its ability to recruit and interact with TLR2. J. Immunol. 2007, 178, 4811-4819.

210. Lee, C.H.; Masso-Welch, P.; Hajishengallis, G.; Connell, T.D. TLR2-dependent modulation of dendritic cells by LT-IIa-B5, a novel mucosal adjuvant derived from a type II heat-labile enterotoxin. J. Leukoc. Biol. 2011, 90, 911-921.

211. Martin, M.; Metzger, D.J.; Michalek, S.M.; Connell, T.D.; Russell, M.W. Comparative analysis of the mucosal adjuvanticity of the type II heat-labile enterotoxins LT-IIa and LT-IIb. Infect. Immun. 2000, 68, 281-287.

212. Mathias-Santos, C.; Rodrigues, J.F.; Sbrogio-Almeida, M.E.; Connell, T.D.; Ferreira, L.C. Distinctive immunomodulatory and inflammatory properties of the Escherichia coli type II heat-labile enterotoxin LT-IIa and its B pentamer following intradermal administration. Clin. Vaccine Immunol. 2011, 18, 1243-1251.

213. Arce, S.; Nawar, H.F.; Russell, M.W.; Connell, T.D. Differential binding of Escherichia coli enterotoxins LT-IIa and LT-IIb and of cholera toxin elicits differences in apoptosis, proliferation, and activation of lymphoid cells. Infect. Immun. 2005, 73, 2718-2727.

214. Nawar, H.F.; Berenson, C.S.; Hajishengallis, G.; Takematsu, H.; Mandell, L.; Clare, R.L.; Connell, T.D. Binding to gangliosides containing $N$-acetylneuraminic acid is sufficient to mediate the immunomodulatory properties of the nontoxic mucosal adjuvant LT-IIb(T13I). Clin. Vaccine Immunol. 2010, 17, 969-978.

215. Greene, C.J.; Chadwick, C.M.; Mandell, L.M.; Hu, J.C.; O’Hara, J.M.; Brey, R.N., III; Mantis, N.J.; Connell, T.D. LT-IIb(T13I), a non-toxic type II heat-labile enterotoxin, augments the capacity of a ricin toxin subunit vaccine to evoke neutralizing antibodies and protective immunity. PLoS One 2013, 8, e69678.

216. Chalifour, A.; Jeannin, P.; Gauchat, J.F.; Blaecke, A.; Malissard, M.; N'Guyen, T.; Thieblemont, N.; Delneste, Y. Direct bacterial protein PAMP recognition by human NK cells involves TLRs and triggers alpha-defensin production. Blood 2004, 104, 1778-1783.

217. Means, T.K.; Hayashi, F.; Smith, K.D.; Aderem, A.; Luster, A.D. The Toll-like receptor 5 stimulus bacterial flagellin induces maturation and chemokine production in human dendritic cells. J. Immunol. 2003, 170, 5165-5175.

218. Didierlaurent, A.; Ferrero, I.; Otten, L.A.; Dubois, B.; Reinhardt, M.; Carlsen, H.; Blomhoff, R.; Akira, S.; Kraehenbuhl, J.P.; Sirard, J.C. Flagellin promotes myeloid differentiation factor 88-dependent development of Th2-type response. J. Immunol. 2004, 172, 6922-6930.

219. McCarron, M.; Reen, D.J. Activated human neonatal $\mathrm{CD}^{+} \mathrm{T}$ cells are subject to immunomodulation by direct TLR2 or TLR5 stimulation. J. Immunol. 2009, 182, 55-62. 
220. Bates, J.T.; Uematsu, S.; Akira, S.; Mizel, S.B. Direct stimulation of $\operatorname{tr} 5^{+/+} \mathrm{CD} 11 \mathrm{c}^{+}$cells is necessary for the adjuvant activity of flagellin. J. Immunol. 2009, 182, 7539-7547.

221. Hayashi, F.; Smith, K.D.; Ozinsky, A.; Hawn, T.R.; Yi, E.C.; Goodlett, D.R.; Eng, J.K.; Akira, S.; Underhill, D.M.; Aderem, A. The innate immune response to bacterial flagellin is mediated by Toll- like receptor 5. Nature 2001, 410, 1099-1103.

222. Liu, F.; Yang, J.; Zhang, Y.; Zhou, D.; Chen, Y.; Gai, W.; Shi, W.; Li, Q.; Tien, P.; Yan, H. Recombinant flagellins with partial deletions of the hypervariable domain lose antigenicity but not mucosal adjuvancy. Biochem. Biophys. Res. Commun. 2010, 392, 582-587.

223. Yang, J.; Zhong, M.; Zhang, Y.; Zhang, E.; Sun, Y.; Cao, Y.; Li, Y.; Zhou, D.; He, B.; Chen, Y.; et al. Antigen replacement of domains D2 and D3 in flagellin promotes mucosal IgA production and attenuates flagellin-induced inflammatory response after intranasal immunization. Hum. Vaccin. Immunother. 2013, 9, 1084-1092.

224. Vijay-Kumar, M.; Carvalho, F.A.; Aitken, J.D.; Fifadara, N.H.; Gewirtz, A.T. TLR5 or NLRC4 is necessary and sufficient for promotion of humoral immunity by flagellin. Eur. J. Immunol. 2010, 40, 3528-3534.

225. Atif, S.M.; Uematsu, S.; Akira, S.; McSorley, S.J. CD103-CD11b ${ }^{+}$dendritic cells regulate the sensitivity of CD4 T-cell responses to bacterial flagellin. Mucosal. Immunol. 2014, 7, 68-77.

226. Asadi Karam, M.R.; Oloomi, M.; Mahdavi, M.; Habibi, M.; Bouzari, S. Vaccination with recombinant FimH fused with flagellin enhances cellular and humoral immunity against urinary tract infection in mice. Vaccine 2013, 31, 1210-1216.

227. Delaney, K.N.; Phipps, J.P.; Johnson, J.B.; Mizel, S.B. A recombinant flagellin-poxvirus fusion protein vaccine elicits complement-dependent protection against respiratory challenge with vaccinia virus in mice. Viral Immunol. 2010, 23, 201-210.

228. Weimer, E.T.; Ervin, S.E.; Wozniak, D.J.; Mizel, S.B. Immunization of young African green monkeys with OprF epitope 8-OprI-type A- and B-flagellin fusion proteins promotes the production of protective antibodies against nonmucoid Pseudomonas aeruginosa. Vaccine 2009, 27, 6762-6769.

229. Krishnan, J.; Lee, G.; Choi, S. Drugs targeting Toll-like receptors. Arch. Pharm. Res. 2009, 32, 1485-1502.

(C) 2014 by the authors; licensee MDPI, Basel, Switzerland. This article is an open access article distributed under the terms and conditions of the Creative Commons Attribution license (http://creativecommons.org/licenses/by/3.0/). 